\title{
DOES PATENT CONTRIBUTE TO STOCK PRICE IN CHINA?
}

\section{DOI: 10.17261/Pressacademia.2019.1021 \\ RJBM- V.6-ISS.1-2019(5)-p.46-67}

\section{Tsui-Min Chen ${ }^{1}$, Chiu-Chi Wei ${ }^{2}$, Hui-Chung $\mathrm{Che}^{3}$}

${ }^{1}$ Chung Hua University, Ph.D. Program of Technology Management, 707, Sec.2, WuFu Rd., Hsinchu, Taiwan. miirchen@gmail.com, ORCID: 0000-0003-0617-8902

2 Chung Hua University, Industrial Management, 707, Sec.2, WuFu Rd., Hsinchu, Taiwan. a0824809@gmail.com, ORCID: 0000-0002-9433-9114

${ }^{3}$ Shenzhen TekGlory IP Data Technologies, Room 201, Site A, Qianwan 1st Rd., Shenzhen, Quandong, China. drcharlie@tek-glory.com, ORCID: 0000-0003-2873-1510

\begin{tabular}{l} 
Date Received: December 15, $2018 \quad$ Date Accepted: March 8, 2018 \\
\hline To cite this document \\
Chen, C. H., Wei, C. C., Che, H. C. (2019). Does patent contribute to stock price in China?. Research Journal of Business and Management \\
(RJBM), V.6(1), p.46-67. \\
Permemant link to this document: http://doi.org/10.17261/Pressacademia.2019.1021 \\
Copyright: Published by PressAcademia and limited licenced re-use rights only.
\end{tabular}

\begin{abstract}
Purpone - Along with the in-depth implementation of national intellectual property strategies in China, China's intellectual property law has been fully integrated with international norms. The number of patents in China is among the highest in the world and China has been the country with the largest number of patent applications in the world for five consecutive years. In addition, the incentive and protective role of the intellectual property system on economy, science, technology and culture has emerged.

Methodology - There are more than 3,000 A-share listed companies in mainland China, as the second largest stock market among global transactions, with the daily trading volume exceeding one trillion RMB. Its ups and downs are catching the eyes of global investors. Patents are the concrete manifestations of scientific and technological innovations. It is questionable if this specific performance can contribute to financial performance and if investment potential stocks can be exploited through patent indicators. In view of this, in this study, an empirical research was conducted on the data of the technology-based enterprises listed on the Shanghai A-share market from 2011 to 2017.

Findings - It is found in this study that, compared to stock prices, there is a significant leading period of specific patent indicators for more than one year. After the data back-testing of the stock exchange, the average performance of the investment potential stocks selected based on this research model is better than the market index performance.

Conclusion - Though the statistical test and time series algorithm of patent indicators, the leading patent formulas are deduced in this study, which can validly predict the stock price of listed companies and the lead period is up to one year, at least a quarter with predictive accuracy.
\end{abstract}

Keywords: Patent, patent indicator, stock price, forecasts, panel data, Granger causality test.

JEL Codes: O34, P14

\section{INTRODUCTION}

According to the "World Economic Situation and Prospects 2018" issued by the United Nations, one-third of global economic growth in 2017 was contributed from China. There are more than 3,000 A-share listed companies in mainland China, with the daily trading volume over 1 trillion RMB, so that the Chinese stock market is the second largest stock market among global transactions and its ups and downs are driving the eyes of global investors.

Since patents have the benefit of protecting research and development results, companies tend to disclose their research and development results in the form of patents. Therefore, compared with disclosed papers on journal articles and technology, patent literatures provide a wealth of research and development information. According to the statistics of the World Intellectual Property Organization (WIPO), 90-95\% of innovations worldwide can be searched in patent literatures (WIPO).

There is no doubt that patents are the concrete manifestations of scientific and technological innovations. However, can innovation results contribute to the financial performance of patent owners? If yes, how can it be measured specifically? If it can be measured, compared to financial information, does patent information belong to a leading indicator or a backward indicator? Such questions have not yet been answered completely in both theory and practice fields. 
In the 1970s, the U.S. CHI Research and the U.S. National Science Foundation (NSF) jointly developed patent-based scientific achievement indicators. CHI Research's patent indicator system was used in the "Science and Engineering Indicators" published by NSF. Many academic studies pointed out that quantity information of patents leads ahead of the sales information of the leading product and thus it has a leading effect in explaining market developments. Consequently, the methods of predicting market trends with patent information have gradually become an important research topic in investment and business evaluation (Narin, 1995; Suh, 2015; Shassan, 2016).

In another aspect, due to large amounts and full disclosure of information in US patents, most of the previous academic articles were based on US patents for research and empirical analysis and related research on patents in mainland China was relatively scarce. However, with the continuous implementation of China's national intellectual property strategy, China's intellectual property laws have been fully integrated with international regulations. The number of patents in mainland China has been among the highest in the world and China has been the country with the largest number of patent applications in the world five consecutive years. At present, the number of patents accumulated has reached 22 million. The role of the intellectual property system in inspiring and guaranteeing the country's economy, science and technology and culture has also begun to appear. Based on such a condition, the causality and transformation of A shares and patents in mainland China has become a topic of great concern in countries, markets, societies, and enterprises.

The official name of China A shares is RMB common stocks, which refer to ordinary stocks registered and listed in China. China's A shares are mainly divided into 1389 Shanghai main boards, 465 Shenzhen main boards, 903 SME boards, 710 GEM boards, etc. Among them, Shanghai main boards not only have the largest number of companies but also the most stateowned enterprises, with more indicative meanings than other boards. Therefore, this study is aimed at a total of 1389 listed companies in Shanghai Main Board to explore the relevance and leadership of patent and financial data by collecting financial and patent data of listed companies from 2011 to 2017. Then, it is attempted to predict the stock price with patent data as a reference for investment stock selection.

This paper is composed of the following sections, the introduction, literature review, method, analysis and results and conclusion.

\section{LITERATURE}

In a patent specification, the patentee must fully disclose the substance and novelty of the technology in order to make patents be granted and thus enjoy the exclusiveness of the patent granted by the law. Once the patent is obtained, the patentee will be given the exclusive advantage during a specific time in the application market of the technology.

Patent indicators based on patent information extraction are different from general technology indicators but has a more substantial ability to observe technology trends (Ernst, 1995; Grag \& Padhi, 1998,). Yan and Liang (2009) have sorted out the development of relevant patent indicators. They organized the definition and usage of patent indicators proposed by $\mathrm{CHI}$ Research and tried to use the quantified patent indicators to explain the company's technology trends and strengths. The Organization for Economic Co-operation and Development (OECD) used patent information to quantify it into patent indicators and divided it into three levels-national analysis indicators, industrial level analysis indicators and enterprise level analysis indicators. Ernst et al. $(1997,2001)$ published research on patent indicators in 2001 and specifically pointed out three types of patent indicators, including relative patent positioning indicators, technical attractiveness indicators, and technical importance indicators, which can be used as a basis for business management, R\&D resource allocation, and strategic R\&D planning.

There are many studies that confirm the utility of patent indicators in corporate financial projections. For example, KaiP (2009) targeted the profitability of the top $50 \%$, the top $25 \%$, and the top $10 \%$ of Danish companies and the company's patent application activities. They conducted correlation analysis by F-test, regression analysis, etc. It was found that the number of patent applications has a significant positive correlation with the company's profit margin. Gao et al. (2013) proposed the S-curves to observe changes in the number of patent applications over time and construct a model to calculate the change in the life cycle of the technology based on multiple patent indicators, of which the results can facilitate investors to assess whether the company is worth investing.

The stock market's stock price forecast attracts many scholars or investors to engage in related research. Lin et al. (2006) found that there is a clear positive correlation in a company using patent portfolios and diversity with the company's investment performance, shareholders' equity and profit margin. Mazzucato et al. (2012) and Hirshleifer et al. (2013) pointed out that the innovation efficiency quantified by the patent indicators is positively correlated with the performance of the stock price. Zhang \& Chen (2013) suggested that when the short-term effects of irrational factors are excluded, the stock price of a company is determined by factors such as the overall performance of the company or the ability of the decision makers to manage in the long run. Consequently, a company's stock price or its technological trends of the industry can be predicted through the overall performance of the company. Vitt \& Xiong (2015) tried to use mathematical models to analyze the relationship between the stock price information of high-tech listed companies of NASDAQ in the 
U.S. and the status of the company's patent activities. The research results proved that there was a positive correlation with two years of deferral between the company's stock price fluctuation and its patent activities.

In addition, patents are linked to long-term and sustainable profits since they represent innovation and realistic outcomes from research across different fields, countries, and periods of time (Trajtenberg 1990; Hullmann \& Meyer, 2003). Jincheol et al. (2017) proposed patent-cited data to provide financial analysts with an assessment of the company's ability to innovate, which has a certain degree of accuracy and can further reduce the uncertainty of the inherent investment technology. Chen \& Chang (2015) pointed out that the enterprises can make a good use of the continuation patent system on patent layouts to protect design patents while suppressing copying or imitating works of continuation patents

\section{METHODOLOGY}

First, in this paper, appropriate target company stock prices and patent data were collected. Then, the patent data were converted into patent indicators. Through Granger causality test, the sample data with a causal relationship with the stock prices were screened. Finally, by using multivariate regression of time sequence, a patent-leading equation that predicts stock prices was established. The details are as follows.

\subsection{Research Steps}

This research is aimed at technology-based enterprises with a sufficient number of patents in Shanghai main boards in mainland China. The research steps are shown in Figure 1. The steps are explained as follows:

(1) Collecting patent and share price information of listed companies: Shanghai Main Board's stock price data and corresponding mainland China's patent data from 2011 to 2017 were collected.

(2) Defining patent indicators: mainland China's patent indicators were defined and patent data of Shanghai Main Board companies are processed to generate patent indicators.

(3) Screening valid samples: the minimum patent number of Shanghai Main Board was set as a valid sample screening threshold and valid samples were screened out.

(4) Six panel data based on modeling period: a set of panel data in a modeling period of two years was formed respectively in the patent index and stock price of the valid sample of Shanghai Main Board and six groups of panel data were divided.

(5) Forming leading indicators of patents through Granger Causality Test: by using patent indicators as independent variables and stock market closing prices as the dependent variable, through the Granger causality test, the leading properties and leading periods of the patent indicators $c$ relative to the stock market closing price in each group's panel data were explored; patent indicators with predictive significance was excavated and defined as leading patent indicators.

(6) Generating significant patent leading formulas: the significant patented leading equations were established in the leading patent indicators of each group through time series.

(7) Forecasting stock prices of each company: the predicted stock prices were calculated based on the patent leading equations in each modeling period.

(8) Calculating the expected rate of return.

(9) Verifying the performance of stock selection: annual and quarterly simulation investments were conducted based on the forecasted rate of return and the simulated investment performance was verified separately with the market average and the SSE Composite Index.

\subsection{Limitation \& Delimitation}

1. The stock exchanges in mainland China include the Shanghai Stock Exchange and the Shenzhen Stock Exchange. In this study, the Shanghai main board was selected as the research object since it has more listed companies, a considerable number of state-owned enterprises, and a particularly strong amount of capital.

2. There are a total of 1389 companies in the Shanghai main boards used in this study. The closing prices of the stock market released on the last trading day of each quarter from 2011 to 2017 were collected as the stock price data for the season. 
Figure 1: Research Flow Chart

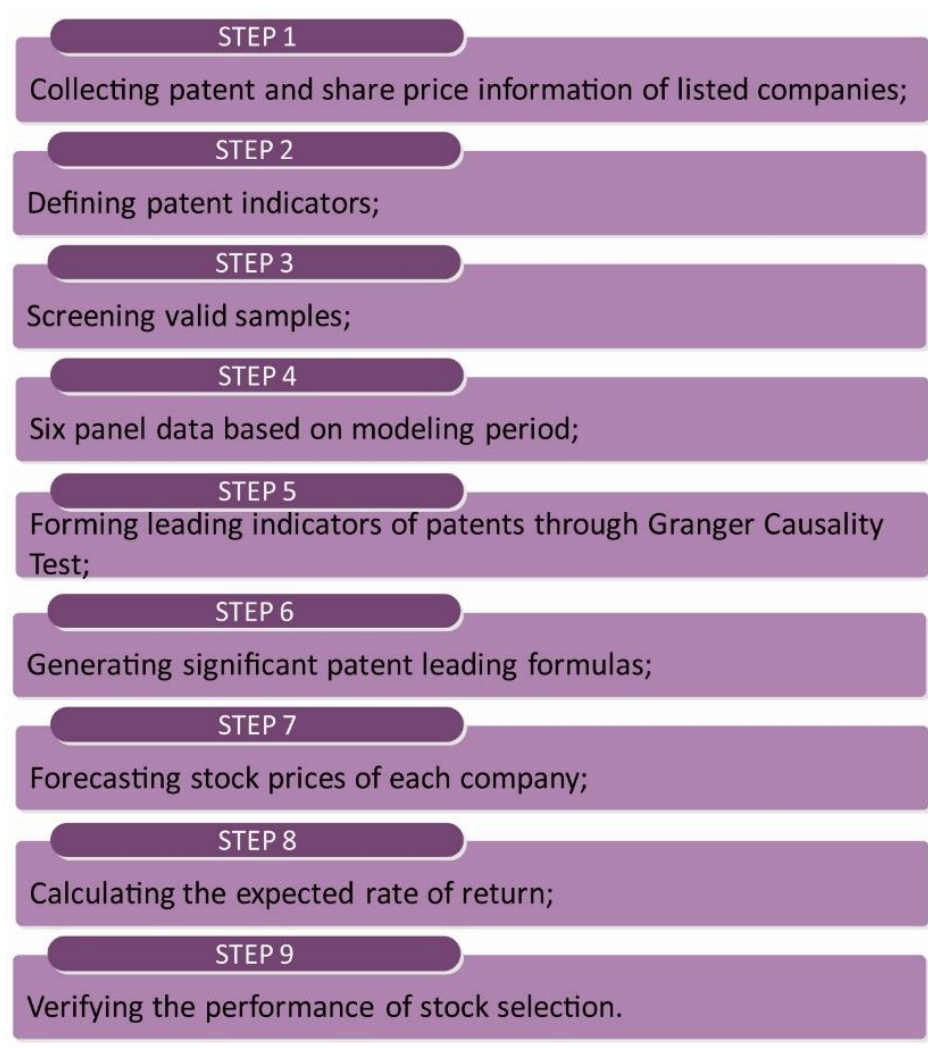

3. If the financial statements of subsidiaries and sub-subsidiaries are also merged with the parent company in the listed company's financial report, it is suggested in this study that the patents of subsidiaries and sub-subsidiaries should also be merged into the parent company. Therefore, this study is based on the list of subsidiaries and subsubsidiaries disclosed in the semi-annual and annual reports of listed companies to conduct calculation by data processing merger to the parent company.

4. In this study, only the impact of mainland China's patents on stock prices was considered. The patents outside mainland China were excluded, such as PCT patents, US patents, European patents, etc.

5. The original data of mainland China's patents used in this study are the patent data published in the patent database of State Intellectual Property Office of the People's Republic of China (SIPO).

\subsection{Instrumentation}

\subsubsection{Granger Causality Test}

Granger Causality Test was developed by Granger, Clive W. J., the 2003 Nobel Prize in Economics (Granger, 1969; Granger, 1980), which is used to analyze Granger causality between economic variables. This is an econometric definition that defines the causal relationship in the sense of time series. To judge whether the independent variable $X$ asscoiated with the dependent variable $Y$, it is needed to examine that the current value of the variable $Y$ can be explained by the past value of the variable $X$ and then to examine whether the adding of the hysteresis value of independent variable $X$ can explain the degree of improvement. If the hysteresis value of the independent variable $X$ helps to improve the degree of interpretation of the dependent variable $Y$, the independent variable $X$ is considered to be the Granger cause of the dependent variable $Y$ (Granger, 1969). That is, the dependent variable can be predicted by observing the independent variable $\mathrm{X}$.

In specific operations, the hysteresis values of the independent variable $\mathrm{X}$ and the dependent variable $\mathrm{Y}$ are frequently used to formulate the regression equation. This is also checked by $\mathrm{F}$ Test and observing $\mathrm{p}$ values. 
The conclusion of the Granger Causality Test is a prediction conclusion, which is the Granger causal relationship in the statistical sense, not the one in the actual sense. Even so, in econometric research, the statistical Granger causality can still play a significant role in economic forecasting.

\subsubsection{Panel Data}

The two-dimensional data with time series and cross-section information is called Panel Data. It can also be called parallel data. From a cross section, panel data are cross-sectional observation values made up of several individuals, such as individuals, families, enterprises and countries, at a certain time. From the longitudinal section, each individual is a time series.

In this study, stock prices are used as dependent variables, patent indicators as independent variables. Therefore, the method of stepwise least squares in Time Series Multi-Regression is used. Mainly under linear conditions, variable combinations which can explain more dependent variable variations are examined. These factors are eventually retained.

\section{ANALYSIS \& RESULTS}

\subsection{Patent Indicators}

Past research has been scarcely involved in mainland China's patent indicators, but the number of patents was mainly explored, instead. As a result, in this study, the exhaustive attack method was adopted to list all possible quantified patent indicators in four steps.

(1) According to the legal status of the patents, patents were divided into two categories: general patents and valid patents. General patents include valid patents and invalid patents. Valid patents include invention licensing patents, utility model patents and design patents which have been approved and annual fees have been continuously paid, as well as the invention disclosure patents that have not yet been filed for review by the entity and have been disclosed and still in the entity review. Invalid patents include the expired announced patents, the approved public notice patents for non-payment of annual fees, the invention disclosure patents that have not passed substantive examination, the invention disclosure patents that have not been examined by entities for more than three years from the date of filing, and the announced patents established by patent invalidation review

(2) According to the patent category, patents are divided into four types: invention disclosure patents, invention approved announced patents, utility model patents and design patents.

(3) Relevant patent indicators were extracted based on information on patent entries, including patent examination period, total IPC classification numbers, patent life, and number of abstract words, etc.

(4) According to the patent text, relevant patent indicators were extracted, including the number of words in specifications, the number of drawings, the number of claims, the number of independent claims, etc.

According to the above steps, a total of 51 patent indicators generated for general patents are shown in Table 1. There are a total of 55 patent indicators generated by valid patents, as shown in Table 2. Since the contribution of patents to companies may take years, the patent data collection periods for different lengths of time were set in this study. The patent index is divided into the one generated by the patent in one year before the current deadline, the one generated by the patent in 2 years before the current deadline, and the one generated by the patent in 10 years before the current deadline. Totally 1060 patent indicators are generated for subsequent analysis. In Table 1 and Table 2, when n=1, P101 represents the number of invention disclosure in the first year before the current deadline, and PA104 represents the number of valid patents granted by the invention in one year before the current deadline; when $n=10, P X 45$ represents the total number of patents in 10 years before the current deadline, and PAX45 represents the total number of valid patents in 10 years before the current deadline.

Table 1: List of Patent Indicators for General Patents

\begin{tabular}{|c|c|c|c|c|c|}
\hline \multirow{2}{*}{ Number } & \multirow{2}{*}{ Definition } & \multicolumn{4}{|c|}{ Patent Category } \\
\hline & & A & M & D & G \\
\hline Pn01 & Number of invention disclosure patents in $\mathrm{n}$ years before the deadline for the current period & $\mathrm{V}$ & & & \\
\hline $\mathrm{Pn} 02$ & Number of utility model patents in $\mathrm{n}$ years before the deadline for the current period & & $\mathrm{V}$ & & \\
\hline Pn03 & Number of design patents in $\mathrm{n}$ years before the current deadline & & & $\mathrm{V}$ & \\
\hline $\mathrm{Pn} 04$ & Number of invention licensing patents in $\mathrm{n}$ years before the deadline for the current period & & & & $\mathrm{V}$ \\
\hline Pn05 & $\begin{array}{l}\text { Average of invention licensing patent examination periods (from application date to approval } \\
\text { announcement date) in } n \text { years before the current deadline }\end{array}$ & & & & $\mathrm{V}$ \\
\hline Pn06 & $\begin{array}{l}\text { Total number of invention disclosure patent IPC classification in } \mathrm{n} \text { years before the current } \\
\text { deadline }\end{array}$ & V & & & \\
\hline
\end{tabular}




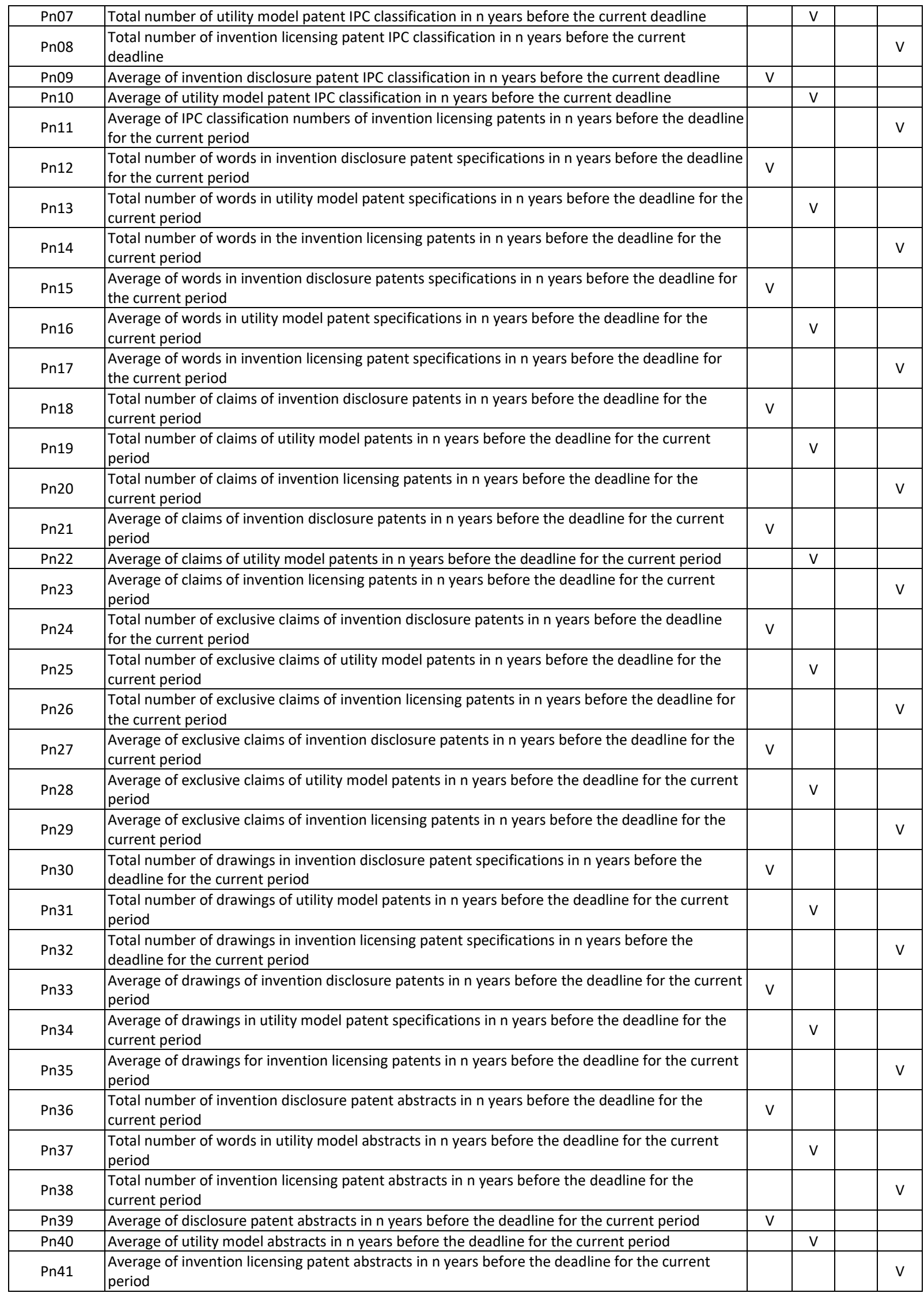




\begin{tabular}{|c|l|c|c|c|c|}
\hline $\mathrm{Pn} 45$ & Total number of patents in $\mathrm{n}$ years before the current deadline & $\mathrm{V}$ & $\mathrm{V}$ & $\mathrm{V}$ & $\mathrm{V}$ \\
\hline $\mathrm{Pn} 46$ & Proportion of invention disclosure patents in $\mathrm{n}$ years before the deadline for the current period & $\mathrm{V}$ & & & \\
\hline $\mathrm{Pn} 47$ & Proportion of utility model patents in $\mathrm{n}$ years before the deadline for the current period & & $\mathrm{V}$ & & \\
\hline $\mathrm{Pn} 48$ & Proportion of design patents in $\mathrm{n}$ years before the deadline for the current period & & $\mathrm{V}$ & \\
\hline $\mathrm{Pn} 49$ & Proportion of invention licensing patents in $\mathrm{n}$ years before the deadline for the current period & & & $\mathrm{V}$ \\
\hline $\mathrm{Pn} 50$ & $\begin{array}{l}\text { Average life expectancy of invention disclosure patents in } \mathrm{n} \text { years before the deadline for the } \\
\text { current period }\end{array}$ & $\mathrm{V}$ & & & \\
\hline $\mathrm{Pn} 51$ & $\begin{array}{l}\text { Average life expectancy of utility model patents in } \mathrm{n} \text { years before the deadline for the current } \\
\text { period }\end{array}$ & $\mathrm{V}$ & & \\
\hline $\mathrm{Pn} 52$ & Average life expectancy of design patents in $\mathrm{n}$ years before the deadline for the current period & & $\mathrm{V}$ & \\
\hline $\mathrm{Pn} 53$ & $\begin{array}{l}\text { Average life expectancy of invention licensing patents in } \mathrm{n} \text { years before the deadline for the } \\
\text { current period }\end{array}$ & & & $\mathrm{V}$ \\
\hline Pn54 & $\begin{array}{l}\text { Total number of invention pre-patent citations in } \mathrm{n} \text { years before the deadline for the current } \\
\text { period }\end{array}$ & & & $\mathrm{V}$ \\
\hline
\end{tabular}

Note: A: invention disclosure patents; M: utility model patents; D: design patents; G: invention licensing patents

\section{Table 2: List of Patent Indicators for Valid Patents}

\begin{tabular}{|c|c|c|c|c|c|}
\hline \multirow{2}{*}{ Number } & \multirow{2}{*}{ Definition } & \multicolumn{4}{|c|}{ Patent Category } \\
\hline & & A & M & D & G \\
\hline PAn01 & Number of valid invention disclosure patents in $\mathrm{n}$ years before the deadline for the current period & $\mathrm{V}$ & & & \\
\hline PAn02 & Number of valid utility model patents in $\mathrm{n}$ years before the deadline for the current period & & $\mathrm{V}$ & & \\
\hline PAn03 & Number of patents valid for design in $\mathrm{n}$ years before the deadline for the current period & & & $\mathrm{V}$ & \\
\hline PAn04 & Number of valid invention licensing patents in $\mathrm{n}$ years before the deadline for the current period & & & & $\mathrm{V}$ \\
\hline PAn05 & $\begin{array}{l}\text { Average of the patent examination period for invention licensing patents in } n \text { years before the } \\
\text { current deadline (from the date of application to the date of approval) }\end{array}$ & & & & V \\
\hline PAn06 & $\begin{array}{l}\text { Total number of valid invention disclosure patent IPC classification numbers in } \mathrm{n} \text { years before the } \\
\text { deadline for the current period }\end{array}$ & V & & & \\
\hline PAn07 & $\begin{array}{l}\text { Total number of valid utility model patent IPC classification numbers in } \mathrm{n} \text { years before the } \\
\text { deadline for the current period }\end{array}$ & & V & & \\
\hline PAn08 & $\begin{array}{l}\text { Total number of invention licensing patent IPC classification numbers in } \mathrm{n} \text { years before the } \\
\text { current deadline }\end{array}$ & & & & V \\
\hline PAn09 & $\begin{array}{l}\text { Average of valid invention disclosure patent IPC classification numbers in } n \text { years before the } \\
\text { deadline for the current period }\end{array}$ & V & & & \\
\hline PAn10 & $\begin{array}{l}\text { Average of valid utility model patent IPC classification numbers in } \mathrm{n} \text { years before the deadline for } \\
\text { the current period }\end{array}$ & & V & & \\
\hline PAn11 & $\begin{array}{l}\text { Average of valid invention licensing patent IPC classification numbers in } n \text { years before the } \\
\text { current deadline }\end{array}$ & & & & V \\
\hline PAn12 & $\begin{array}{l}\text { Total number of words of valid invention disclosure patents in } \mathrm{n} \text { years before the deadline for the } \\
\text { current period }\end{array}$ & V & & & \\
\hline PAn13 & $\begin{array}{l}\text { Total number of valid utility model patent specifications in } \mathrm{n} \text { years before the deadline for the } \\
\text { current period }\end{array}$ & & V & & \\
\hline PAn14 & $\begin{array}{l}\text { Total number of words in valid invention licensing patent specifications in } \mathrm{n} \text { years before the } \\
\text { current deadline }\end{array}$ & & & & V \\
\hline PAn15 & $\begin{array}{l}\text { Average of words of valid invention disclosure patents in } \mathrm{n} \text { years before the deadline for the } \\
\text { current period }\end{array}$ & V & & & \\
\hline PAn16 & $\begin{array}{l}\text { Average of valid utility model patent specifications in } n \text { years before the deadline for the current } \\
\text { period }\end{array}$ & & V & & \\
\hline PAn17 & $\begin{array}{l}\text { Average of words in valid invention licensing patent specifications in } n \text { years before the deadline } \\
\text { for the current period }\end{array}$ & & & & V \\
\hline PAn18 & $\begin{array}{l}\text { Total number of claims of valid invention disclosure patents in } \mathrm{n} \text { years before the deadline for the } \\
\text { current period }\end{array}$ & V & & & \\
\hline PAn19 & $\begin{array}{l}\text { Total number of claims of valid utility model patents in } \mathrm{n} \text { years before the deadline for the current } \\
\text { period }\end{array}$ & & V & & \\
\hline PAn20 & $\begin{array}{l}\text { Total number of claims of invention of valid invention licensing patents in } n \text { years before the } \\
\text { deadline for the current period }\end{array}$ & & & & V \\
\hline PAn21 & $\begin{array}{l}\text { Average of claims of valid invention disclosure patents in } n \text { years before the deadline for the } \\
\text { current period }\end{array}$ & V & & & \\
\hline PAn22 & $\begin{array}{l}\text { Average of claims of valid utility model patents in } n \text { years before the deadline for the current } \\
\text { period }\end{array}$ & & V & & \\
\hline PAn23 & $\begin{array}{l}\text { Average of claims of valid invention licensing patent in } n \text { years before the deadline for the current } \\
\text { period }\end{array}$ & & & & V \\
\hline PAn24 & $\begin{array}{l}\text { Total number of exclusive claims of valid invention disclosure patents in } n \text { years before the } \\
\text { deadline for the current period }\end{array}$ & V & & & \\
\hline
\end{tabular}




\begin{tabular}{|c|c|c|c|c|c|}
\hline PAn25 & $\begin{array}{l}\text { Total number of exclusive claims of valid utility model patents in } n \text { years before the deadline for } \\
\text { the current period }\end{array}$ & & v & & \\
\hline PAn26 & $\begin{array}{l}\text { Total number of exclusive claims of valid invention licensing patents in } \mathrm{n} \text { years before the } \\
\text { deadline for the current period }\end{array}$ & & & & V \\
\hline PAn27 & $\begin{array}{l}\text { Average of exclusive claims of valid invention disclosure patents in } \mathrm{n} \text { years before the deadline for } \\
\text { the current period }\end{array}$ & V & & & \\
\hline PAn28 & $\begin{array}{l}\text { Average of exclusive claims of valid utility model patents in } n \text { years before the deadline for the } \\
\text { current period }\end{array}$ & & v & & \\
\hline PAn29 & $\begin{array}{l}\text { Average of exclusive claims of valid invention licensing patents in } \mathrm{n} \text { years before the deadline for } \\
\text { the current period }\end{array}$ & & & & V \\
\hline PAn30 & $\begin{array}{l}\text { Total number of drawings in valid invention disclosure patent specifications in } \mathrm{n} \text { years before the } \\
\text { deadline for the current period }\end{array}$ & v & & & \\
\hline PAn31 & $\begin{array}{l}\text { Total number of drawings of valid utility model patent in } \mathrm{n} \text { years before the deadline for the } \\
\text { current period }\end{array}$ & & v & & \\
\hline PAn32 & $\begin{array}{l}\text { Total number of drawings for valid invention licensing patents in } \mathrm{n} \text { years before the deadline for } \\
\text { the current period }\end{array}$ & & & & V \\
\hline PAn33 & $\begin{array}{l}\text { Average of drawings invalid invention disclosure patent specifications in } \mathrm{n} \text { years before the } \\
\text { deadline for the current period }\end{array}$ & v & & & \\
\hline PAn34 & $\begin{array}{l}\text { Average of drawings in valid utility model patent specifications in } n \text { years before the deadline for } \\
\text { the current period }\end{array}$ & & v & & \\
\hline PAn35 & $\begin{array}{l}\text { Average of drawings in valid invention licensing patent specifications in } \mathrm{n} \text { years before the } \\
\text { deadline for the current period }\end{array}$ & & & & V \\
\hline PAn36 & $\begin{array}{l}\text { Total number of valid invention disclosure patent abstracts in } \mathrm{n} \text { years before the deadline for the } \\
\text { current period }\end{array}$ & v & & & \\
\hline PAn37 & $\begin{array}{l}\text { Total number of valid utility model patent abstracts in } \mathrm{n} \text { years before the deadline for the current } \\
\text { period }\end{array}$ & & v & & \\
\hline PAn38 & $\begin{array}{l}\text { Total number of valid invention licensing patent abstracts in } \mathrm{n} \text { years before the deadline for the } \\
\text { current period }\end{array}$ & & & & V \\
\hline PAn39 & $\begin{array}{l}\text { Average of words of valid invention disclosure patents in } \mathrm{n} \text { years before the deadline for the } \\
\text { current period }\end{array}$ & v & & & \\
\hline PAn40 & $\begin{array}{l}\text { Average of valid utility model patent abstracts in } \mathrm{n} \text { years before the deadline for the current } \\
\text { period }\end{array}$ & & v & & \\
\hline PAn41 & $\begin{array}{l}\text { Average of valid invention licensing patent abstracts in } \mathrm{n} \text { years before the deadline for the current } \\
\text { period }\end{array}$ & & & & V \\
\hline PAn45 & Total number of valid patents in $\mathrm{n}$ years before the current deadline & $\mathrm{V}$ & $\mathrm{V}$ & $\mathrm{V}$ & $\mathrm{V}$ \\
\hline PAn46 & $\begin{array}{l}\text { Proportion of valid invention disclosure patents in all invention disclosure patents in } \mathrm{n} \text { years } \\
\text { before the deadline for the current period }\end{array}$ & $\mathrm{V}$ & & & \\
\hline PAn47 & $\begin{array}{l}\text { Proportion of valid utility model patents in all utility model patents in } n \text { years before the deadline } \\
\text { for the current period }\end{array}$ & & $\mathrm{v}$ & & \\
\hline PAn48 & Proportion of valid design patents in all design patents in $n$ years before the current deadline & & & $\mathrm{V}$ & \\
\hline PAn49 & $\begin{array}{l}\text { Proportion of valid invention licensing patents in all invention licensing patents in } n \text { years before } \\
\text { the deadline for the current period }\end{array}$ & & & & $\mathrm{V}$ \\
\hline PAn50 & $\begin{array}{l}\text { Average life expectancy of valid invention disclosure patents in } \mathrm{n} \text { years before the current } \\
\text { deadline }\end{array}$ & $\mathrm{V}$ & & & \\
\hline PAn51 & $\begin{array}{l}\text { Average life expectancy of valid utility model patents in } n \text { years before the deadline for the } \\
\text { current period }\end{array}$ & & $\mathrm{V}$ & & \\
\hline PAn52 & Average life expectancy of valid design patents in $\mathrm{n}$ years before the current deadline & & & $\mathrm{V}$ & \\
\hline PAn53 & Average life expectancy of valid invention licensing patents in $n$ years before the current deadline & & & & $\mathrm{V}$ \\
\hline PAn54 & $\begin{array}{l}\text { Total number of valid pre-patent citations for invention licensing patent } \\
\text { before n-year deadline }\end{array}$ & & & & $\mathrm{V}$ \\
\hline PAn55 & $\begin{array}{l}\text { Proportion of valid invention disclosure patents in } \mathrm{n} \text { years before the deadline for the current } \\
\text { period }\end{array}$ & $\mathrm{v}$ & & & \\
\hline PAn56 & Proportion of valid utility model patents in $n$ years before the deadline for the current period & & $\mathrm{V}$ & & \\
\hline PAn57 & Proportion of valid design patents in $\mathrm{n}$ years before the deadline for the current period & & & $\mathrm{V}$ & \\
\hline PAn58 & $\begin{array}{c}\text { Proportion of valid invention licensing patents in } \mathrm{n} \text { years before the deadline for the current } \\
\text { period }\end{array}$ & & & & $\mathrm{V}$ \\
\hline
\end{tabular}

Note: A: invention disclosure patents; M: utility model patents; D: design patents; G: invention licensing patents

\subsection{Population and Sample}

As of the end of 2017, there were a total of 3,467 Mainland China A-share listed companies, including Shanghai main boards, Shenzhen main boards, SME boards, GEM boards, etc. In this study, 1,389 listed companies of Shanghai's main boards are analyzed, accounting for $40 \%$ of the total A shares in China. 
Since the number of listed companies is not fixed but gradually increases and some companies are also delisted from the market, thus, every two years is used as a modeling period from 2011 to 2017 in this study to explore the impact of patent indicators on stock prices and the forecasting effect in each modeling period.

Valid samples must meet two conditions during the modeling period:

1. During the modeling period, there is at least one patent in total in ten years; that is, the total number of patents PAX45>0; and

2. During the modeling period, there must be closing price data when there is no suspension of trading on the last trading day of each year.

Table 3 shows the number of valid samples and sampling rates for the Shanghai main boards from 2011 to 2017 in the six modeling periods in this study. In Table 3, the trend of patent development in mainland China is also shown. In the modeling period (1) from 2011 to 2012, the proportion of companies with no zero patents in Shanghai main boards is only 41\%. In the modeling period (6) from 2016 to 2017, the proportion of companies with no zero patents has reached 65\%. The growth rate is very impressive.

Table 3: Valid Samples for Each Modeling Period

\begin{tabular}{|c|c|c|c|}
\hline \multicolumn{2}{|c|}{ Modeling Period } & Effective Number of Samples & Sampling Rate \\
\hline$(1)$ & $2011^{\sim} 2012$ & 566 & $0.41 \%$ \\
\hline$(2)$ & $2012^{\sim} 2013$ & 631 & $0.45 \%$ \\
\hline$(3)$ & $2013^{\sim} 2014$ & 684 & $0.49 \%$ \\
\hline$(4)$ & $2014^{\sim} 2015$ & 717 & $0.52 \%$ \\
\hline$(5)$ & $2015^{\sim} 2016$ & 812 & $0.58 \%$ \\
\hline$(6)$ & $2016^{\sim} 2017$ & 902 & $0.65 \%$ \\
\hline
\end{tabular}

\subsection{Balanced Panel Data}

This study is based on quarters. Six balance panel data are formulated for the six modeling periods of the Shanghai main boards. In each panel data, the stock price of the valid sample on the last trading day of each quarter and 1060 patent indicator data for the trading day are included.

By the Kolmogorov-Smirnov test, in this study, it is found that in each of the above panel data, both stock price data and patent indicator data are not normally distributed. Therefore, Box-Cox conversion was conducted for each panel indicator data in this study and then subsequent analysis is performed.

\subsection{Granger Causality Test}

In this study, Granger Causality Test was adopted to examine the leading relationship of each patent indicator to the stock price in turn for 6 panel data. In statistical tests, the $F$ test was adopted, $p$ value was adopted in model fit, the time leading period is 4 quarters, and the analysis software E-views 7.0 was used.

Through the Granger Causality test, it is found in this study that there are certain patent indicators that can lead to a fourquarter lead property in stock prices, which is calls the leading patent indicator in this study. Tables 4-9 are the significant leading patent indicators that have been unearthed during each modeling period.

Table 4: Leading Patent Indicators in Modeling Period (1) from 2011 to 2012

\begin{tabular}{|c|l|l|}
\hline Leading patent indicators & Definition of leading patent indicators & p value \\
\hline P151 & $\begin{array}{l}\text { Average life expectancy of utility model patents in one year before the deadline for } \\
\text { the current period }\end{array}$ & $0.0031^{* *}$ \\
\hline P327 & $\begin{array}{l}\text { Average of exclusive claims of invention disclosure patents } \\
\text { in 3 years before the deadline for the current period }\end{array}$ & $0.0001^{* * *}$ \\
\hline P339 & $\begin{array}{l}\text { Average of disclosure patent abstracts in the three years before the deadline for the } \\
\text { current period }\end{array}$ & $0.0000^{* * *}$ \\
\hline P402 & Number of utility model patents in 4 years before the deadline for the current period & $0.0000^{* * *}$ \\
\hline P418 & $\begin{array}{l}\text { Total number of claims of invention disclosure patents } \\
\text { in 4 years before the deadline for the current period }\end{array}$ & $0.0001^{* * *}$ \\
\hline P421 & $\begin{array}{l}\text { Average of claims of invention disclosure patents in 4 years before the deadline for } \\
\text { the current period }\end{array}$ & $0.0000^{* * *}$ \\
\hline P427 & $\begin{array}{l}\text { Average of exclusive claims of invention disclosure patents } \\
\text { in 4 years before the deadline for the current period }\end{array}$ & $0.0009^{* * *}$ \\
\hline
\end{tabular}




\begin{tabular}{|c|l|c|}
\hline P454 & $\begin{array}{l}\text { Total number of invention pre-patent citations in } 4 \text { years before the deadline for the } \\
\text { current period }\end{array}$ & $0.0000^{* * *}$ \\
\hline P613 & $\begin{array}{l}\text { Total number of words in utility model patent specifications in } 6 \text { years before the } \\
\text { deadline for the current period }\end{array}$ & $0.0015^{* *}$ \\
\hline P713 & $\begin{array}{l}\text { Total number of words in utility model patent specifications in } 7 \text { years before the } \\
\text { deadline for the current period }\end{array}$ & $0.0000^{* * *}$ \\
\hline P851 & $\begin{array}{l}\text { Average life expectancy of utility model patents in } 8 \text { years before the deadline for the } \\
\text { current period }\end{array}$ & $0.0000^{* * *}$ \\
\hline PA715 & $\begin{array}{l}\text { Average of words of valid invention disclosure patent specifications in 7 years before } \\
\text { the deadline for the current period }\end{array}$ & $0.0001 * * *$ \\
\hline PA721 & $\begin{array}{l}\text { Average of claims of valid invention disclosure patents in 7 years before the deadline } \\
\text { for the current period }\end{array}$ & $0.0010^{* *}$ \\
\hline PA727 & $\begin{array}{l}\text { Average of exclusive claims of valid invention disclosure patents } \\
\text { in 7 years before the deadline for the current period }\end{array}$ & $0.0034 * *$ \\
\hline PA927 & $\begin{array}{l}\text { Average of exclusive claims of valid invention disclosure patents in } 9 \text { years before the } \\
\text { deadline for the current period }\end{array}$ & $0.0000^{* * *}$ \\
\hline
\end{tabular}

\section{Table 5: Leading Patent Indicators in Modeling Period (2) from 2012 to 2013}

\begin{tabular}{|c|c|c|}
\hline Leading patent indicators & Definition of leading patent indicators & $p$ value \\
\hline P106 & $\begin{array}{l}\text { Total number of invention disclosure patent IPC classification numbers in one year } \\
\text { before the current deadline }\end{array}$ & $0.0354 * *$ \\
\hline P115 & $\begin{array}{l}\text { Average of words of invention disclosure patent specifications in one year before the } \\
\text { deadline for the current period }\end{array}$ & $0.0032 * *$ \\
\hline P127 & $\begin{array}{l}\text { Average of exclusive claims of invention disclosure patents in one year before the } \\
\text { deadline for the current period }\end{array}$ & $0.0000 * * *$ \\
\hline P133 & $\begin{array}{l}\text { Average of drawings in invention disclosure patent specifications in one year before } \\
\text { the current deadline }\end{array}$ & $0.0027^{* *}$ \\
\hline P139 & $\begin{array}{l}\text { Average of invention disclosure patent abstracts in the first year before the deadline } \\
\text { for the current period }\end{array}$ & $0.0000 * * *$ \\
\hline P146 & $\begin{array}{l}\text { Proportion of invention disclosure patents in one year before the deadline for the } \\
\text { current period }\end{array}$ & $0.0000 * * *$ \\
\hline $\mathrm{P} 240$ & Average of utility model abstracts in 2 years before the deadline for the current period & $0.0321 * *$ \\
\hline P251 & $\begin{array}{l}\text { Average life expectancy of utility model patents in } 2 \text { years before the deadline for the } \\
\text { current period }\end{array}$ & $0.0002^{* * *}$ \\
\hline P352 & $\begin{array}{l}\text { Average life expectancy of design patents in } 3 \text { years before the deadline for the } \\
\text { current period }\end{array}$ & $0.0062 * *$ \\
\hline P547 & $\begin{array}{l}\text { Proportion of utility model patents in } 5 \text { years before the deadline for the current } \\
\text { period }\end{array}$ & $0.0005^{* * *}$ \\
\hline P703 & Number of design patents in 7 years before the current deadline & $0.0005^{* * *}$ \\
\hline P903 & Number of design patents in 9 years before the deadline for the current period & $0.0003 * * *$ \\
\hline PA106 & $\begin{array}{l}\text { Total number of valid invention disclosure patent IPC classification numbers in one } \\
\text { year before the current deadline }\end{array}$ & $0.0000 * * *$ \\
\hline PA118 & $\begin{array}{l}\text { Total number of claims of valid invention disclosure patents in one year before the } \\
\text { deadline for the current period }\end{array}$ & $0.0000 * * *$ \\
\hline PA121 & $\begin{array}{l}\text { Average of claims of valid invention disclosure patents in one year before the deadline } \\
\text { for the current period }\end{array}$ & $0.0000 * * *$ \\
\hline PA124 & $\begin{array}{l}\text { Total number of exclusive claims of valid invention disclosure patents in one year } \\
\text { before the deadline for the current period }\end{array}$ & $0.0000 * * *$ \\
\hline PA150 & $\begin{array}{l}\text { Average life expectancy of valid invention disclosure patents in one year before the } \\
\text { deadline for the current period }\end{array}$ & $0.0005^{* * *}$ \\
\hline PA155 & $\begin{array}{l}\text { Proportion of valid invention disclosure patents in one year before the deadline for } \\
\text { the current period }\end{array}$ & $0.0000^{* * *}$ \\
\hline PA345 & Total number of valid patents in 3 years before the current deadline & $0.0002 * * *$ \\
\hline PA408 & $\begin{array}{l}\text { Total number of valid invention licensing patent IPC classification numbers in } 4 \text { years } \\
\text { before the current deadline }\end{array}$ & $0.0001^{* * *}$ \\
\hline PA648 & $\begin{array}{l}\text { Proportion of valid design patents in all design patents in } 6 \text { years prior to the current } \\
\text { deadline }\end{array}$ & $0.0349 * *$ \\
\hline PA803 & Number of valid design patents in 8 years before the deadline for the current period & $0.0010 * * *$ \\
\hline
\end{tabular}


Table 6: Leading Patent Indicators in Modeling Period (3) from 2013 to 2014

\begin{tabular}{|c|c|c|}
\hline Leading patent indicators & Definition of leading patent indicators & p value \\
\hline P551 & $\begin{array}{l}\text { Average life expectancy of utility model patents in } 5 \text { years before the deadline for } \\
\text { the current period }\end{array}$ & $0.0044^{* *}$ \\
\hline P651 & $\begin{array}{l}\text { Average life expectancy of utility model patents in } 6 \text { years before the deadline for } \\
\text { the current period }\end{array}$ & $0.0009 * * *$ \\
\hline P751 & $\begin{array}{l}\text { Average life expectancy of utility model patents in } 7 \text { years before the deadline for } \\
\text { the current period }\end{array}$ & $0.0455^{* *}$ \\
\hline P952 & $\begin{array}{l}\text { Average life expectancy of design patents in } 9 \text { years before the deadline for the } \\
\text { current period }\end{array}$ & $0.0000 * * *$ \\
\hline PA154 & $\begin{array}{l}\text { Total number of pre-patent citations for invention licensing patents in one year } \\
\text { before the current deadline }\end{array}$ & $0.0000 * * *$ \\
\hline PA316 & $\begin{array}{l}\text { Average of words of the valid utility model patent specifications in } 3 \text { years before } \\
\text { the deadline for the current period }\end{array}$ & $0.0000^{* * *}$ \\
\hline PA351 & $\begin{array}{l}\text { Average life expectancy of valid utility model patent in } 3 \text { years before the deadline } \\
\text { for the current period }\end{array}$ & $0.0000 * * *$ \\
\hline PA354 & $\begin{array}{l}\text { Total number of pre-patent citations for invention licensing patents in } 3 \text { years before } \\
\text { the deadline for the current period }\end{array}$ & $0.0037^{* *}$ \\
\hline PA540 & $\begin{array}{l}\text { Average of valid utility model patent abstracts in } 5 \text { years before the deadline for the } \\
\text { current period }\end{array}$ & $0.0000 * * *$ \\
\hline PA551 & $\begin{array}{l}\text { Average life expectancy of valid utility model patent in } 5 \text { years before the deadline } \\
\text { for the current period }\end{array}$ & $0.0000 * * *$ \\
\hline
\end{tabular}

Table 7: Leading Patent Indicators in Modeling Period (4) from 2014 to 2015

\begin{tabular}{|c|l|l|}
\hline $\begin{array}{c}\text { Leading patent } \\
\text { indicators }\end{array}$ & Definition of leading patent indicators & p value \\
\hline P336 & $\begin{array}{l}\text { Total number of invention disclosure patent abstracts in 3 years before the } \\
\text { deadline for the current period }\end{array}$ & $0.0014^{* *}$ \\
\hline P446 & $\begin{array}{l}\text { Proportion of invention disclosure patents in 4 years before the deadline for } \\
\text { the current period }\end{array}$ & $0.0000^{* * *}$ \\
\hline P652 & $\begin{array}{l}\text { Average life expectancy of design patents in 6 years before the deadline for } \\
\text { the current period }\end{array}$ & $0.0000^{* * *}$ \\
\hline P804 & $\begin{array}{l}\text { Number of invention licensing patents in 8 years before the deadline for the } \\
\text { current period }\end{array}$ & $0.0000^{* * *}$ \\
\hline PX27 & $\begin{array}{l}\text { Average of exclusive claims of invention disclosure patents in 10 years before } \\
\text { the deadline for the current period }\end{array}$ & $0.0226^{* *}$ \\
\hline PA106 & $\begin{array}{l}\text { Total number of valid invention disclosure patent IPC classification numbers in } \\
\text { one year before the current deadline }\end{array}$ & $0.0319^{* *}$ \\
\hline PA454 & $\begin{array}{l}\text { Total number of pre-patent citations for invention licensing patents in 4 years } \\
\text { before the deadline for the current period }\end{array}$ & $0.0025^{* *}$ \\
\hline PA532 & $\begin{array}{l}\text { Total number of drawings in valid invention licensing patent specifications in } 5 \\
\text { years before the deadline for the current period }\end{array}$ & $0.0018^{* *}$ \\
\hline PA732 & $\begin{array}{l}\text { Total number of drawings in valid invention licensing patent specifications in } 7 \\
\text { years before the current deadline }\end{array}$ & $0.0250^{* *}$ \\
\hline
\end{tabular}

Table 8: Leading Patent Indicators in Modeling Period (5) from 2015 to 2016

\begin{tabular}{|c|l|l|}
\hline Leading patent indicators & Definition of leading patent indicators & p value \\
\hline P154 & Total number of invention pre-patent citations in one year before the deadline for the current period & .0083** \\
\hline P346 & Proportion of invention disclosure patents in 3 years before the deadline for the current period \\
\hline P646 & Proportion of invention disclosure patents in 6 years before the deadline for the current period & $.0004 * *$ \\
\hline PA305 & Average of valid invention licensing patent examination periods in 3 years before the deadline for the & current period (from the date of application to the date of approval) \\
\hline PA353 & Average life expectancy of invention licensing patents in 3 years before the current deadline \\
\hline PA957 & Proportion of valid design patents in 9 years before the deadline for the current period \\
\hline
\end{tabular}

Note: $p^{* *}<0.05, p^{* * *}<0.001$ 
Table 9: Leading Patent Indicators in Modeling Period (6) Patent Leading Indicators from 2016 to 2017

\begin{tabular}{|c|c|c|}
\hline Leading patent indicators & Definition of leading patent indicators & p value \\
\hline P127 & $\begin{array}{l}\text { Average of exclusive claims of invention licensing patents in one year before the deadline for the current } \\
\text { period }\end{array}$ & $0.0148^{* *}$ \\
\hline P234 & $\begin{array}{l}\text { Average of drawings of utility model patent specifications in } 2 \text { years before the deadline for the current } \\
\text { period }\end{array}$ & $0.0011 * * *$ \\
\hline P301 & Number of invention disclosure patents in 3 years before the deadline for the current period & $0.0008 * * *$ \\
\hline P310 & $\begin{array}{l}\text { Average of utility model patent IPC classification numbers in } 3 \text { years before the deadline for the current } \\
\text { period }\end{array}$ & $0.0002 * * *$ \\
\hline P410 & $\begin{array}{l}\text { Average of utility model patent IPC classification numbers in } 4 \text { years before the deadline for the current } \\
\text { period }\end{array}$ & $0.0208 * *$ \\
\hline P510 & $\begin{array}{l}\text { Average of utility model patent IPC classification numbers in } 5 \text { years before the deadline for the current } \\
\text { period }\end{array}$ & $0.0000 * * *$ \\
\hline P547 & Proportion of utility model patents in 5 years before the deadline for the current period & $0.0168 * *$ \\
\hline P704 & Number of invention licensing patents in 7 years before the deadline for the current period & $0.0000 * * *$ \\
\hline PA110 & $\begin{array}{l}\text { Average of valid utility model patent IPC classification numbers in one year before the deadline for the } \\
\text { current period }\end{array}$ & $0.0000 * * *$ \\
\hline PA116 & Average of valid utility model patent specifications in one year before the deadline for the current perioc & $0.0000^{* * *}$ \\
\hline PA450 & $\begin{array}{l}\text { Average life expectancy of valid invention disclosure patents in } 4 \text { years before the deadline for the } \\
\text { current period }\end{array}$ & $0.0000 * * *$ \\
\hline PA454 & $\begin{array}{l}\text { Total number of pre-patent citations for invention licensing patents in } 4 \text { years before the deadline for th } \\
\text { current period }\end{array}$ & $0.0001^{* * *}$ \\
\hline PA726 & $\begin{array}{l}\text { Total number of exclusive claims of valid invention licensing patents in } 7 \text { years before the deadline for } \\
\text { the current period }\end{array}$ & $0.0000 * * *$ \\
\hline PA754 & Total number of pre-patent citations for invention licensing patent in 7 years before the current deadline & $0.0011^{* *}$ \\
\hline PAX50 & $\begin{array}{l}\text { Average life expectancy of valid invention disclosure patents in } 10 \text { years before the deadline for the } \\
\text { current period }\end{array}$ & $0.0004^{* * *}$ \\
\hline
\end{tabular}

Tables 4-9 show 77 leading patent indicators unearthed in 6 modeling periods. However, the number of leading patent indicators in each model period is very different. As shown in Table 10, the modeling period (2) has the most 22 leading patent indicators. But there are only six leading patent indicators in the modeling period (5).

Table 10: Number of Leading Patent Indicators in Each Modeling Period

\begin{tabular}{|c|c|c|c|c|c|c|}
\hline Modeling period & (1) & (2) & (3) & (4) & (5) & (6) \\
\hline $\begin{array}{l}\text { Number of leading patent } \\
\text { indicators }\end{array}$ & 15 & 22 & 10 & 9 & 6 & 15 \\
\hline
\end{tabular}

Simultaneously, the leading patent indicators in the six modeling periods are different. There are 4 indicators repeating in the two modeling periods, as shown in Table 11. The reason for the inference in this study is the implementation of the planned economy in mainland China. Policies guide patent outputs. Besides, the stock market fluctuates greatly and the stock price changes dramatically. Therefore, the leading patent indicators generated are not the same.

Table 11: The Leading Patent Indicators Appearing More than Twice

\begin{tabular}{|c|c|c|c|}
\hline $\begin{array}{l}\text { Leading patent } \\
\text { indicators }\end{array}$ & Definition of leading patent indicators & $\begin{array}{l}\text { Modeling } \\
\text { period }\end{array}$ & p value \\
\hline \multirow{2}{*}{ P127 } & \multirow{2}{*}{$\begin{array}{l}\text { Average of exclusive claims of invention disclosure patents } \\
\text { in one year before the deadline }\end{array}$} & $(2)$ & $0.0000 * * *$ \\
\hline & & (6) & $0.0148 * *$ \\
\hline \multirow{2}{*}{ P547 } & \multirow{2}{*}{ Proportion of utility model patents in 5 years before the deadline for the current period } & (2) & $0.0005 * * *$ \\
\hline & & (6) & $0.0168^{* *}$ \\
\hline \multirow{2}{*}{ PA106 } & \multirow{2}{*}{$\begin{array}{l}\text { Total number of valid invention disclosure patent IPC classification numbers in one year } \\
\text { before the current deadline }\end{array}$} & $(2)$ & $0.0000 * * *$ \\
\hline & & (4) & $0.0319 * *$ \\
\hline \multirow{2}{*}{ PA454 } & \multirow{2}{*}{$\begin{array}{l}\text { Total number of pre-patent citations for invention licensing patents in } 4 \text { years before the } \\
\text { deadline for the current period }\end{array}$} & (4) & $0.0025^{* *}$ \\
\hline & & (6) & $0.0001 * * *$ \\
\hline
\end{tabular}

In the six modeling periods, there are a total of 77 leading patent indicators, with 73 after deducting duplicates. Among them, there are 41 leading patent indicators for general patents, 32 for valid patents. The number is slightly lower than the former, but the gap is not big. 
As shown in Table 12, among the 73 leading patent indicators, the number of leading patent indicators related to invention disclosure- 30-is the largest and there are nine leading patent indicators for design patents, which is the fewest amounts. Although many industry experts consistently pointed out that mainland Chin's utility model patents is filled with too many garbage patents and thus the quality is not high. It is found in this study that the impact of leading patent indicators of utility model patents on stock prices of Shanghai main boards is preceded only by that of invention disclosure patents, even greater than the impact of invention licensing patent.

Table 12: Number of Leading Patent Indicators in Each Modeling Period

\begin{tabular}{|l|l|c|}
\hline Patent type & \multicolumn{1}{|c|}{ Leading patent indicators } & Quantity \\
\hline Invention disclosure patents & $\begin{array}{l}\text { P301,P106,P115,P418,P421,P127,P327,P427,PX27,P133,P336,P139,P339,P146,P346,P446,P646,PA1 } \\
\text { 06,PA715,PA118,PA121,PA721,PA124,PA727,PA927,PA345,PA150,PA450,PAX50,PA155 }\end{array}$ \\
\hline \multirow{2}{*}{ Utility model patents } & $\begin{array}{l}\text { P402,P310,P410,P510,P613,P713,P234,P240,P547,P151,P251,P551,P651,P751,P851,PA110,PA116,P } \\
\text { A316,PA540,PA345,PA351,PA551 }\end{array}$ \\
\hline Design patents & P703,P903,P352,P652,P952,PA803,PA345,PA648,PA957 & 9 \\
\hline Invention licensing patents & P704,P804,P154,P454,PA305,PA408,PA726,PA532,PA732,PA345,PA353,PA154,PA354,PA454,PA754 & 14 \\
\hline
\end{tabular}

In considering the patent data collection period P1 PX and PA1 PAX, the analysis results of 77 leading patent indicators are shown in Table 13. Whether it is a general patent or a valid patent, all of them have the largest number of leading patent indicators in the patent in one year before the current deadline.

Table 13: Number of Leading Patent Indicators for Each Patent Data Collection Cycle

\begin{tabular}{|c|c|c|c|c|c|c|c|c|c|c|}
\hline Patent data collection cycle & P1 & $\mathrm{P} 2$ & P3 & P4 & P5 & P6 & P7 & P8 & P9 & PX \\
\hline Number of leading patent indicators & 9 & 3 & 7 & 7 & 4 & 4 & 4 & 2 & 2 & 1 \\
\hline Patent data collection cycle & PA1 & PA2 & PA3 & PA4 & PA5 & PA6 & PA7 & PA8 & PA9 & PAX \\
\hline Number of leading patent indicators & 10 & 0 & 6 & 4 & 3 & 1 & 6 & 1 & 2 & 1 \\
\hline
\end{tabular}

\subsection{Patent Leading Equation for Forecasting Stock Price}

In this study, it is further attempted to introduce leading patent indicators for each modeling period. Through a multiple regression equation of time series, the patented leading equations which can be used to predict stock prices are formulated. The dependent variable is the stock price; the dependent variable is the leading patent indicator for each modeling period; the time leading period is 4 quarters; $p<0.05$ for each leading patent indicator in the regression equation; the analysis software E-views 7.0 is used. The result is shown in equation (1), in which yf is the predicted stock price, $y(-4)$ is the stock price before 4 quarters, xi $(-4)$ is the leading patent indicator before 4 quarters, and ci $(-4)$ is the corresponding weight of the aforementioned leading patent indicator.

$$
y_{f}=y_{(-4)}+\sum c_{i(-4)} \cdot x_{i(-4)}
$$

Tables 14-19 are the analysis results of the modeling period (1) to the modeling period (6), the leading patent indicators and corresponding weight coefficients in the patent leading equation.

The patent leading equations obtained by Tables 14 to 19, the data value of the patent indicator for each sample in each modeling period is entered into the patent leading equation so that a predicted stock price after 4 quarters can be generated. POOP is the predicted stock price.

Table 14: Patent Leading Equations in Modeling Period (1) and Leading Patent Indicators

\begin{tabular}{|c|c|c|c|c|}
\hline Variable & Coefficient & Std. Error & t-Statistic & Prob. \\
\hline C & 0.841157 & 0.582341 & 1.44444 & 0.1488 \\
\hline P00P(-4) & 0.835827 & 0.009864 & 84.73811 & 0.0000 \\
\hline P737(-4) & -2.44723 & 0.397846 & -6.15121 & 0.0000 \\
\hline P851(-4) & 2.033975 & 0.369239 & 5.508562 & 0.0000 \\
\hline P312(-4) & 1.708316 & 0.39416 & 4.334072 & 0.0000 \\
\hline PA721(-4) & 2.466544 & 0.551007 & 4.476432 & 0.0000 \\
\hline PAX21(-4) & -3.18304 & 0.52828 & -6.0253 & 0.0000 \\
\hline P415(-4) & -1.31743 & 0.280787 & -4.69191 & 0.0000 \\
\hline
\end{tabular}




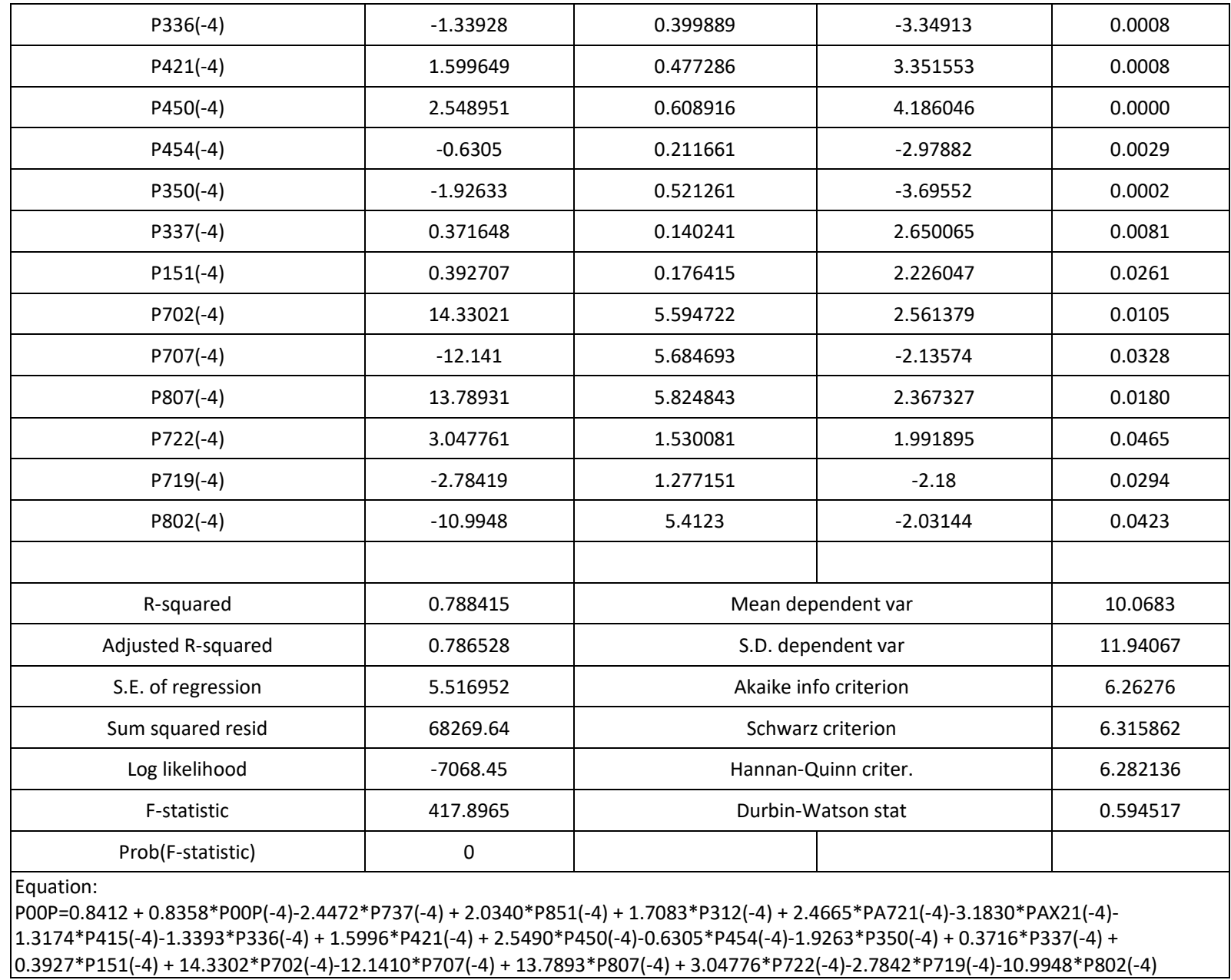

Table 15: Patent Leading Equations in Modeling Period (2) and Leading Patent Indicators

\begin{tabular}{|c|c|c|c|c|}
\hline Variable & Coefficient & Std. Error & t-Statistic & Prob. \\
\hline C & 2.959471 & 0.406262 & 7.284633 & 0.0000 \\
\hline P00P(-4) & 0.779724 & 0.009119 & 85.50553 & 0.0000 \\
\hline P251(-4) & -1.83839 & 0.492736 & -3.73097 & 0.0002 \\
\hline PA803(-4) & 0.630953 & 0.19147 & 3.295308 & 0.0010 \\
\hline PA118(-4) & 4.009357 & 0.709799 & 5.648581 & 0.0000 \\
\hline P139(-4) & -2.25969 & 0.390267 & -5.79011 & 0.0000 \\
\hline P115(-4) & 0.841935 & 0.28515 & 2.952599 & 0.0032 \\
\hline P133(-4) & 0.657023 & 0.219164 & 2.997859 & 0.0027 \\
\hline PA124(-4) & -5.41678 & 0.734777 & -7.372 & 0.0000 \\
\hline PA648(-4) & -1.45807 & 0.690759 & -2.11082 & 0.0349 \\
\hline P547(-4) & 2.762177 & 0.794507 & 3.476591 & 0.0005 \\
\hline PA345(-4) & -0.74121 & 0.200629 & -3.69441 & 0.0002 \\
\hline PA408(-4) & 0.480201 & 0.123442 & 3.890076 & 0.0001 \\
\hline P352(-4) & 0.342782 & 0.125057 & 2.74101 & 0.0062 \\
\hline P703(-4) & -1.73772 & 0.497711 & -3.49142 & 0.0005 \\
\hline
\end{tabular}




\begin{tabular}{|c|c|c|c|c|}
\hline PA106(-4) & 1.560442 & 0.381521 & 4.090056 & 0.0000 \\
\hline PA155(-4) & -5.06727 & 1.177143 & -4.30472 & 0.0000 \\
\hline P146(-4) & 5.261095 & 1.182183 & 4.450323 & 0.0000 \\
\hline P127(-4) & 5.82234 & 1.086687 & 5.35788 & 0.0000 \\
\hline PA150(-4) & 0.994068 & 0.284817 & 3.490201 & 0.0005 \\
\hline P106(-4) & -0.52614 & 0.249923 & -2.10521 & 0.0354 \\
\hline P240(-4) & 0.589514 & 0.274976 & 2.143874 & 0.0321 \\
\hline P903(-4) & 1.671314 & 0.460783 & 3.627119 & 0.0003 \\
\hline PA121(-4) & -3.36242 & 0.710963 & -4.72939 & 0.0000 \\
\hline R-squared & 0.772193 & \multicolumn{2}{|c|}{ Mean dependent var } & 10.1525 \\
\hline Adjusted R-squared & 0.770097 & \multicolumn{2}{|c|}{ S.D. dependent var } & 10.5135 \\
\hline S.E. of regression & 5.041039 & \multicolumn{2}{|c|}{ Akaike info criterion } & 6.0826 \\
\hline Sum squared resid & 63530.18 & \multicolumn{2}{|c|}{ Schwarz criterion } & 6.1380 \\
\hline Log likelihood & -7652.2 & \multicolumn{2}{|c|}{ Hannan-Quinn criter. } & 6.1027 \\
\hline F-statistic & 368.4431 & \multicolumn{2}{|c|}{ Durbin-Watson stat } & 0.7028 \\
\hline Prob(F-statistic) & 0 & & & \\
\hline \multicolumn{5}{|c|}{ 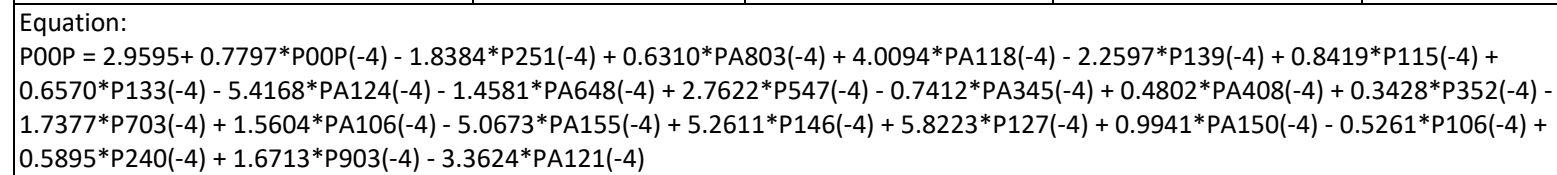 } \\
\hline
\end{tabular}

Table 16: Patent Leading Equations in Modeling Period (3) and Leading Patent Indicators

\begin{tabular}{|c|c|c|c|c|}
\hline Variable & Coefficient & Std. Error & t-Statistic & Prob. \\
\hline C & 1.577418 & 0.349866 & 4.50864 & 0.0000 \\
\hline P00P(-4) & 0.848653 & 0.00926 & 91.65084 & 0.0000 \\
\hline P952(-4) & 0.244374 & 0.054649 & 4.47173 & 0.0000 \\
\hline PA551(-4) & 2.275224 & 0.441558 & 5.15272 & 0.0000 \\
\hline PA540(-4) & -1.447055 & 0.321833 & -4.496284 & 0.0000 \\
\hline PA154(-4) & -0.655351 & 0.14239 & -4.602501 & 0.0000 \\
\hline PA351(-4) & -1.957759 & 0.453836 & -4.313805 & 0.0000 \\
\hline PA354(-4) & 0.383858 & 0.132044 & 2.907041 & 0.0037 \\
\hline P651(-4) & 1.471069 & 0.444409 & 3.310169 & 0.0009 \\
\hline PA316(-4) & 1.044026 & 0.217934 & 4.790556 & 0.0000 \\
\hline P551(-4) & -1.03312 & 0.362448 & -2.850399 & 0.0044 \\
\hline P751(-4) & -0.588537 & 0.294136 & -2.000904 & 0.0455 \\
\hline & & & & 11.3624 \\
\hline R-squared & 0.760104 & Mean dependent var & 10.2250 \\
\hline Adjusted R-squared & 0.759135 & S.D. dependent var & 6.0684 \\
\hline S.E. of regression & 5.018221 & Akaike info criterion & 6.0943 \\
\hline Sum squared resid & 68597.24 & Schwarz criterion & 6.0778 \\
\hline Log likelihood & -8289.577 & & & \\
\hline
\end{tabular}




\begin{tabular}{|l|c|c|c|}
\hline \multicolumn{1}{|c|}{ F-statistic } & 784.6283 & 0.7839 & Durbin-Watson stat \\
\hline \multicolumn{1}{|c|}{ Prob(F-statistic) } & 0 & & \\
\hline $\begin{array}{l}\text { Equation: } \\
\text { P00P = 1.5774+ 0.8487*P0OP(-4) + 0.2444*P952(-4) + 2.2752*PA551(-4) - 1.4471*PA540(-4) - 0.6554*PA154(-4) - 1.9578*PA351(-4) + } \\
0.3839 * P A 354(-4)+1.4711 * P 651(-4)+1.0440 * P A 316(-4)-1.0331 * P 551(-4)-0.5885 * P 751(-4)\end{array}$ \\
\hline
\end{tabular}

Table 17: Patent Leading Equations in Modeling Period (4) and Leading Patent Indicators

\begin{tabular}{|c|c|c|c|c|}
\hline Variable & Coefficient & Std. Error & t-Statistic & Prob. \\
\hline C & 3.763391 & 0.786049 & 4.787728 & 0.0000 \\
\hline POOP(-4) & 1.07829 & 0.016317 & 66.08289 & 0.0000 \\
\hline P652(-4) & 0.484007 & 0.100393 & 4.821124 & 0.0000 \\
\hline P446(-4) & 6.051136 & 1.405183 & 4.306297 & 0.0000 \\
\hline P336(-4) & -0.363875 & 0.113431 & -3.20788 & 0.0014 \\
\hline PA454(-4) & 0.663111 & 0.219329 & 3.023358 & 0.0025 \\
\hline PA532(-4) & 2.139734 & 0.68634 & 3.117602 & 0.0018 \\
\hline P804(-4) & -1.211239 & 0.264745 & -4.575121 & 0.0000 \\
\hline PA106(-4) & -0.397548 & 0.18519 & -2.146707 & 0.0319 \\
\hline PA732(-4) & -1.553003 & 0.692356 & -2.243071 & 0.0250 \\
\hline P9X27(-4) & 2.197706 & 0.963378 & 2.281251 & 0.0226 \\
\hline R-squared & 0.620152 & \multicolumn{2}{|c|}{ Mean dependent var } & 16.9038 \\
\hline Adjusted R-squared & 0.618822 & \multicolumn{2}{|c|}{ S.D. dependent var } & 14.2540 \\
\hline S.E. of regression & 8.800368 & \multicolumn{2}{|c|}{ Akaike info criterion } & 7.1913 \\
\hline Sum squared resid & 221264.6 & \multicolumn{2}{|c|}{ Schwarz criterion } & 7.2142 \\
\hline Log likelihood & -10301.31 & \multicolumn{2}{|c|}{ Hannan-Quinn criter. } & 7.1995 \\
\hline F-statistic & 466.443 & \multicolumn{2}{|c|}{ Durbin-Watson stat } & 1.2090 \\
\hline Prob(F-statistic) & 0 & & & \\
\hline \multicolumn{5}{|c|}{$\begin{array}{l}\text { Equation: } \\
\text { P00P }=3.7634+1.0783 * \text { POOP(-4) + 0.4840*P652(-4) + 6.0511*P446(-4) - 0.3639*P336(-4) +0.6631*PA454(-4) + 2.1397*PA532(-4) - } \\
1.2112 * \text { P804(-4) - 0.3975*PA106(-4) - 1.5530*PA732(-4) + 2.198*P9X27(-4) }\end{array}$} \\
\hline
\end{tabular}

Table 18: Patent Leading Equations in Modeling Period (5) and Leading Patent Indicators

\begin{tabular}{|c|c|c|c|c|}
\hline Variable & Coefficient & Std. Error & t-Statistic & Prob. \\
\hline C & 1.902511 & 0.480068 & 3.963003 & 0.0001 \\
\hline $\mathrm{POOP}(-4)$ & 0.730298 & 0.009579 & 76.24078 & 0.0000 \\
\hline P346(-4) & -7.15773 & 2.024659 & -3.535276 & 0.0004 \\
\hline P154(-4) & -0.453012 & 0.171422 & -2.642665 & 0.0083 \\
\hline P646(-4) & 4.884481 & 2.199672 & 2.22055 & 0.0265 \\
\hline PA353(-4) & 2.243115 & 0.899016 & 2.495079 & 0.0126 \\
\hline PA305(-4) & -2.552889 & 1.01027 & -2.526938 & 0.0116 \\
\hline PA957(-4) & 3.791098 & 1.104362 & 3.432839 & 0.0006 \\
\hline R-squared & 0.65209 & \multicolumn{2}{|c|}{ Mean dependent var } & 14.8275 \\
\hline Adjusted R-squared & 0.651338 & \multicolumn{2}{|c|}{ S.D. dependent var } & 14.4778 \\
\hline
\end{tabular}




\begin{tabular}{|c|c|c|c|}
\hline S.E. of regression & 8.54881 & Akaike info criterion & 7.1319 \\
\hline Sum squared resid & 236786.2 & Schwarz criterion & 7.1469 \\
\hline Log likelihood & -11574.24 & Hannan-Quinn criter. & 7.1373 \\
\hline \multicolumn{1}{|c|}{ F-statistic } & 867.5349 & Durbin-Watson stat & 0.9100 \\
\hline \multicolumn{1}{|c|}{ Prob(F-statistic) } & 0 & & \\
\hline $\begin{array}{l}\text { Equation: } \\
\text { 3.7911*PA957(-4) }=1.9025+0.7303 * P 00 P(-4)-7.1577 * P 346(-4)-0.4530 * P 154(-4)+4.8845 * P 646(-4)+2.2431 * P A 353(-4)-2.5529 * P A 305(-4)+\end{array}$ \\
\hline
\end{tabular}

Table 19: Patent Leading Equations in Modeling Period (6) and Leading Patent Indicators

\begin{tabular}{|c|c|c|c|c|}
\hline Variable & Coefficient & Std. Error & t-Statistic & Prob.* \\
\hline $\mathrm{C}$ & -4.89761 & 0.785187 & -6.23751 & 0 \\
\hline P0OP(-4) & 1.159395 & 0.012095 & 95.85803 & 0 \\
\hline P704(-4) & 4.982735 & 0.768051 & 6.487506 & 0 \\
\hline PA726(-4) & -3.4847 & 0.691153 & -5.04187 & 0 \\
\hline P410(-4) & 3.845131 & 1.663182 & 2.311912 & 0.0208 \\
\hline PA116(-4) & 0.834049 & 0.128012 & 6.515403 & 0 \\
\hline PA110(-4) & -5.57434 & 0.894465 & -6.23204 & 0 \\
\hline P310(-4) & 4.480997 & 1.20786 & 3.709866 & 0.0002 \\
\hline P510(-4) & -5.60965 & 1.313333 & -4.2713 & 0 \\
\hline P234(-4) & -1.39314 & 0.426589 & -3.26576 & 0.0011 \\
\hline P547(-4) & -2.81349 & 1.17626 & -2.39189 & 0.0168 \\
\hline PA450(-4) & -1.43949 & 0.300122 & -4.79636 & 0 \\
\hline PAX50(-4) & 1.03034 & 0.292468 & 3.522915 & 0.0004 \\
\hline P301(-4) & -0.88526 & 0.264558 & -3.34617 & 0.0008 \\
\hline PA454(-4) & 1.151493 & 0.285223 & 4.037172 & 0.0001 \\
\hline PA754(-4) & -1.03701 & 0.317255 & -3.26869 & 0.0011 \\
\hline P127(-4) & 1.580641 & 0.647941 & 2.439484 & 0.0148 \\
\hline R-squared & 0.726926 & \multicolumn{2}{|c|}{ Mean dependent var } & 14.58766 \\
\hline Adjusted R-squared & 0.725709 & \multicolumn{2}{|c|}{ S.D. dependent var } & 20.08943 \\
\hline S.E. of regression & 10.52139 & \multicolumn{2}{|c|}{ Akaike info criterion } & 7.549399 \\
\hline Sum squared resid & 397522.7 & \multicolumn{2}{|c|}{ Schwarz criterion } & 7.578569 \\
\hline Log likelihood & -13602.1 & \multicolumn{2}{|c|}{ Hannan-Quinn criter. } & 7.559793 \\
\hline F-statistic & 597.4548 & \multicolumn{2}{|c|}{ Durbin-Watson stat } & 0.44492 \\
\hline Prob(F-statistic) & 0 & & & \\
\hline \multicolumn{5}{|c|}{$\begin{array}{l}\text { Equation: } \\
\text { P00P }=-4.8976+1.1594 * \text { P00P(-4) + 4.9827*P704(-4) - 3.4847*PA726(-4) + 3.8451*P410(-4) + 0.8340*PA116(-4) - 5.5743*PA110(-4) + } \\
\text { 4.4810*P310(-4) - 5.610*P510(-4) - 1.3931*P234(-4) - 2.8135*P547(-4) - 1.4395*PA450(-4) + 1.0303*PAX50(-4)-0.8853*P301(-4)+ } \\
1.1515 * P A 454(-4)-1.0370 * P A 754(-4)+1.5806 * P 127(-4)\end{array}$} \\
\hline
\end{tabular}




\subsection{Building Stock Portfolio by Forecasting Profit Rate}

In terms of investment behavior, choosing stocks based on the "yield rate," instead of the "high stock price," is the easiest in understanding investment stock selection criteria. For example, there are two stocks-A shares and B shares, with the current value of the stock price is $10 \mathrm{RMB}$ and $100 \mathrm{RMB}$ respectively. It is supposed that after one year, the stock price will rise by $10 \mathrm{RMB}$ to $20 \mathrm{RMB}$ and $110 \mathrm{RMB}$ respectively. It is assumed that one buys $B$ shares with a single fund and the yield after one year is $10 \%$; one buys $A$ shares with the same funds and the yield after one year is $100 \%$.

Then, we use the "predicted annual rate of return" as the basis for stock selection, as shown in equation (2), where Profit_Rate $_{f}$ is the predicted rate of return after one year, Stock $\boldsymbol{f}_{f}$ is the predicted stock price for a year after the patentleading equation is generated, and Stock $\boldsymbol{k}_{c}$ is the current stock price.

\section{Profit_Rate $_{f}=\left(\right.$ Stock $_{f}-$ Stock $\left._{c}\right) /$ Stock $_{c}$}

Table 20 shows the performance of the forecasting annual rate of return stock selection for Shanghai main boards during the six modeling periods proposed in the research, in which the average sample performance is the average annual yield of sample stocks during the modeling period. TOP30 is the average annual rate of return for the top 30 stocks selected based on the forecasted annual rate of return. TOP50 is the average annual rate of return for the top 50 stocks selected based on the forecasted annual rate of return.

Table 20 shows the average annual rate of return for all selected TOP30 and TOP50 in 6 modeling periods. 24 time intervals are better than the average performance of the samples during the modeling period, in which the average annual rate of return for TOP30 in the 14 time intervals is better than that for TOP50. It shows that in this study, the stock selection investment on an annual basis was successful, where stock prices are predicted through patent leading equations and then the predicted rate of return is generated from the predicted stock prices.

Table 20: Sample Average Performance and Stock Selection Performance During Modeling Period

\begin{tabular}{|c|c|c|c|c|c|}
\hline Modeling period & $\begin{array}{c}\text { Number of } \\
\text { samples }\end{array}$ & Time interval & $\begin{array}{c}\text { Annual sample average } \\
\text { performance }\end{array}$ & TOP30 & TOP50 \\
\hline \multirow{4}{*}{ (1) 2011-2012 } & \multirow{4}{*}{566} & 2011Q1 2012Q1 & -0.3369 & -0.2936 & -0.2436 \\
\hline & & 2011Q2 2012Q2 & -0.2701 & -0.2104 & -0.2510 \\
\hline & & 2011Q3 2012Q3 & -0.3247 & -0.2146 & -0.1291 \\
\hline & & 2011Q4 2012Q4 & -0.0146 & 0.0116 & 0.0176 \\
\hline \multirow{4}{*}{ (2) 2012-2013 } & \multirow{4}{*}{631} & 2012Q1 2013Q1 & -0.0034 & 0.0533 & 0.0579 \\
\hline & & 2012Q2 2013Q2 & -0.0931 & -0.0377 & -0.0255 \\
\hline & & 2012Q3 2013Q3 & 0.1555 & 0.1778 & 0.2181 \\
\hline & & 2012Q4 2013Q4 & 0.1175 & 0.1829 & 0.2092 \\
\hline \multirow{4}{*}{ (3) 2013-2014 } & \multirow{4}{*}{684} & $2013 Q 1$ 2014Q1 & 0.0457 & 0.1553 & 0.1432 \\
\hline & & 2013Q2 2014Q2 & 0.1859 & 0.3447 & 0.2783 \\
\hline & & 2013Q3 2014Q3 & 0.2660 & 0.4542 & 0.4156 \\
\hline & & 2013Q4 2014Q4 & 0.4116 & 0.8525 & 0.7956 \\
\hline \multirow{4}{*}{ (4) 2014-2015 } & \multirow{4}{*}{717} & 2014Q1 2015Q1 & 0.8898 & 1.4688 & 1.3637 \\
\hline & & 2014Q2 2015Q2 & 1.2744 & 2.5200 & 2.3980 \\
\hline & & 2014Q3 2015Q3 & 0.1800 & 0.5657 & 0.6295 \\
\hline & & 2014Q4 2015Q4 & 0.3458 & 0.4781 & 0.4526 \\
\hline \multirow{4}{*}{ (5) 2015-2016 } & \multirow{4}{*}{812} & 2015Q1 2016Q1 & -0.1644 & -0.0210 & -0.0772 \\
\hline & & 2015Q2 2016Q2 & -0.3224 & -0.1797 & -0.1963 \\
\hline & & 2015Q3 2016Q3 & 0.0628 & 0.1930 & 0.1647 \\
\hline & & 2015Q4 2016Q4 & -0.1494 & -0.0646 & -0.0858 \\
\hline
\end{tabular}




\begin{tabular}{|l|l|l|l|l|l|}
\hline & & $2016 Q 1 \sim 2017 Q 1$ & 0.0317 & 0.0951 & 0.1013 \\
\cline { 3 - 6 } (6) 2016-2017 & \multirow{4}{*}{902} & $2016 Q 2 \sim 2017 Q 2$ & -0.0344 & -0.0100 & 0.0086 \\
\cline { 3 - 6 } & & $2016 Q 3 \sim 2017 Q 3$ & -0.0100 & 0.1412 & 0.1425 \\
\hline & & $2016 Q 4 \sim 2017 Q 4$ & -0.1069 & -0.0364 & -0.0036 \\
\hline
\end{tabular}

\subsection{Validation by Comparing Shanghai A-Share Index 000001}

In addition, in this study, the SSE Composite Index (stock code: 000001) is used to compare the quarterly rate of return. The full name of the SSE Composite Index is the Shanghai Stock Exchange's stock price composite index, which is mainly to reflect the statistical indicators of the overall trend of listed stocks on the Shanghai Stock Exchange. Its base value is 100. All listed stocks are taken as samples and the issued amount of stocks is as the weights to conduct compilation.

In this study, the patented leading equations for six modeling periods are utilized to perform simulation investment calculations. In order to facilitate calculations, the closing prices are adopted for calculation throughout the study. The simulated investment capital is 1 million RMB; the investment began in the first quarter of 2011 (referred to as 2011Q1) and ended in the fourth quarter of 2017 (referred to as 2017Q4). Stock conversion and investment performance calculation is conducted every season. The operation steps of the simulated investment are as follows: Table 21 and Figure 2 are the annual yield performance analysis table and the comparison chart of TOP30 and TOP50 selected according to the model proposed in this study compared with the SSE Composite Index 000001.

1. In terms of the predicted rate of return calculated based on leading patent equations for each modeling period, the top 30/top 50 stocks with the highest rate of return forecasted for $2011 \mathrm{Q} 1$ are purchased. All stocks are sold in the next quarter 2011Q2, and the investment performance is calculated.

2. The funds after selling the stocks in following step 1 are the new investment capital. On the same day, the top 30/top 50 stocks with the highest rate of return forecasted for 201102 are bought, all stocks are sold in the next quarter 2011Q3, and the investment performance is calculated.

3. The funds after selling the stocks in following step 2 are the new investment capital. On the same day, the top 30/top 50 stocks with the highest rate of return forecasted for 201103 are bought, all stocks are sold in the next quarter 2011Q4, and the investment performance is calculated.

4. And so forth, the top $30 / 50$ companies calculated in the six-stage modeling period of this study are selected as stock picking logic and converted into stocks each season, and the investment performance of each quarter is calculated till $2017 Q 4$.

According to the model proposed in this study, the TOP30 and TOP50 stocks are selected to conduct simulation investment for share conversion operation. Compared to the investment performance analysis of the SSE Composite Index, it can be seen that based on the average quarterly rate of return, except for 2011Q4, the investment performance of TOP30 is superior to the performance of the SSE Composite Index each season. The investment performance of TOP50 gradually outperforms the SSE Composite Index after 2013Q1, which also pulls out a very obvious difference in investment performance until the end of 2017Q4.

This shows that the Stock Selection Models based on the patent index proposed in this study have relatively better investment performance in conversion investment operation no matter on an annual basis or on a quarterly basis. In addition, it is also found in this study that the performance of TOP50 is better among the investments of conversion investment on an annual basis and the performance of TOP30 is better among the investments of conversion investment on a quarterly basis.

Table 21: Performance of TOP30/ TOP50 vs SSE Composite Index

\begin{tabular}{|c|c|c|c|c|c|}
\hline \multirow{2}{*}{ Date } & \multicolumn{3}{|c|}{ Investment performance } & \multicolumn{2}{c|}{ Average rate of return } \\
\cline { 2 - 6 } & SSE Composite Index & T30 & T50 & T30 & T50 \\
\hline $2011 \mathrm{Q} 1$ & $100.00 \%$ & $100.00 \%$ & $100.00 \%$ & $100.00 \%$ & $100.00 \%$ \\
\hline $2011 \mathrm{Q} 2$ & $94.33 \%$ & $95.31 \%$ & $91.33 \%$ & $-4.69 \%$ & $-8.67 \%$ \\
\hline $2011 \mathrm{Q} 3$ & $80.57 \%$ & $84.48 \%$ & $78.97 \%$ & $-11.36 \%$ & $-13.53 \%$ \\
\hline $2011 \mathrm{Q} 4$ & $75.11 \%$ & $73.77 \%$ & $66.71 \%$ & $-12.68 \%$ & $-15.53 \%$ \\
\hline
\end{tabular}




\begin{tabular}{|c|c|c|c|c|c|}
\hline 2012Q1 & $77.28 \%$ & $81.91 \%$ & $72.30 \%$ & $11.03 \%$ & $8.38 \%$ \\
\hline 2012Q2 & $76.00 \%$ & $83.29 \%$ & $72.61 \%$ & $1.69 \%$ & $0.43 \%$ \\
\hline $2012 Q 3$ & $71.25 \%$ & $78.39 \%$ & $67.36 \%$ & $-5.89 \%$ & $-7.23 \%$ \\
\hline $2012 Q 4$ & $77.49 \%$ & $85.34 \%$ & $72.53 \%$ & $8.87 \%$ & $7.67 \%$ \\
\hline 2013Q1 & $76.38 \%$ & $93.66 \%$ & $81.30 \%$ & $9.75 \%$ & $12.10 \%$ \\
\hline 2013Q2 & $67.59 \%$ & $82.90 \%$ & $70.81 \%$ & $-11.49 \%$ & $-12.91 \%$ \\
\hline $2013 Q 3$ & $74.27 \%$ & $100.65 \%$ & $85.50 \%$ & $21.42 \%$ & $20.75 \%$ \\
\hline $2013 Q 4$ & $72.26 \%$ & $111.63 \%$ & $85.60 \%$ & $10.90 \%$ & $0.12 \%$ \\
\hline $2014 Q 1$ & $69.44 \%$ & $112.57 \%$ & $86.17 \%$ & $0.85 \%$ & $0.67 \%$ \\
\hline 2014Q2 & $69.95 \%$ & $113.02 \%$ & $88.46 \%$ & $0.40 \%$ & $2.65 \%$ \\
\hline $2014 Q 3$ & $80.73 \%$ & $157.23 \%$ & $120.43 \%$ & $39.11 \%$ & $36.14 \%$ \\
\hline 2014Q4 & $110.47 \%$ & $234.88 \%$ & $167.08 \%$ & $49.39 \%$ & $38.74 \%$ \\
\hline 2015Q1 & $128.00 \%$ & $337.32 \%$ & $237.79 \%$ & $43.61 \%$ & $42.32 \%$ \\
\hline $2015 Q 2$ & $146.07 \%$ & $453.89 \%$ & $311.84 \%$ & $34.56 \%$ & $31.14 \%$ \\
\hline 2015Q3 & $104.26 \%$ & $321.13 \%$ & $216.60 \%$ & $-29.25 \%$ & $-30.54 \%$ \\
\hline 2015Q4 & $120.87 \%$ & $467.37 \%$ & $307.99 \%$ & $45.54 \%$ & $42.19 \%$ \\
\hline 2016Q1 & $102.59 \%$ & $407.55 \%$ & $261.05 \%$ & $-12.80 \%$ & $-15.24 \%$ \\
\hline 2016Q2 & $100.05 \%$ & $413.78 \%$ & $270.13 \%$ & $1.53 \%$ & $3.48 \%$ \\
\hline 2016Q3 & $102.62 \%$ & $518.68 \%$ & $336.72 \%$ & $25.35 \%$ & $24.65 \%$ \\
\hline $2016 Q 4$ & $105.99 \%$ & $646.27 \%$ & $416.12 \%$ & $24.60 \%$ & $23.58 \%$ \\
\hline 2017Q1 & $110.05 \%$ & $794.98 \%$ & $503.34 \%$ & $23.01 \%$ & $20.96 \%$ \\
\hline 2017Q2 & $109.03 \%$ & $957.16 \%$ & $589.81 \%$ & $20.40 \%$ & $17.18 \%$ \\
\hline $2017 Q 3$ & $114.37 \%$ & $1431.43 \%$ & $824.14 \%$ & $49.55 \%$ & $39.73 \%$ \\
\hline 2017Q4 & $112.95 \%$ & $2016.31 \%$ & $1073.45 \%$ & $40.86 \%$ & $30.25 \%$ \\
\hline
\end{tabular}

\section{CONCLUSION}

This study is the first attempt to analyze the correlation between the patent index and stock price of the A-share Shanghai Main Board listed companies in mainland China. Though the statistical test and time series algorithm of patent indicators, the leading patent formulas are deduced in this study, which can validly predict the stock price of listed companies and the lead period is up to one year, at least a quarter with predictive accuracy. Based on the investment potential stocks selected in this study, the stock exchange operation is carried out on an annual basis. Its investment performance is significantly better than the current average performance of Shanghai main boards. The results represent that this research can validly tap the investment potential stocks in Shanghai main boards to improve investment efficiency. Based on the investment potential stocks selected in this study, the stock exchange operation is carried out on a quarterly basis. The investment performance is compared with the SSE Composite Index. It is found that the performance of the investment potential stocks selected by this research model is even better, which indicates that the model proposed in this study can be useful in short-term predictions. 
Figure 2: Performance of TOP30/ TOP50 vs. SSE Composite Index

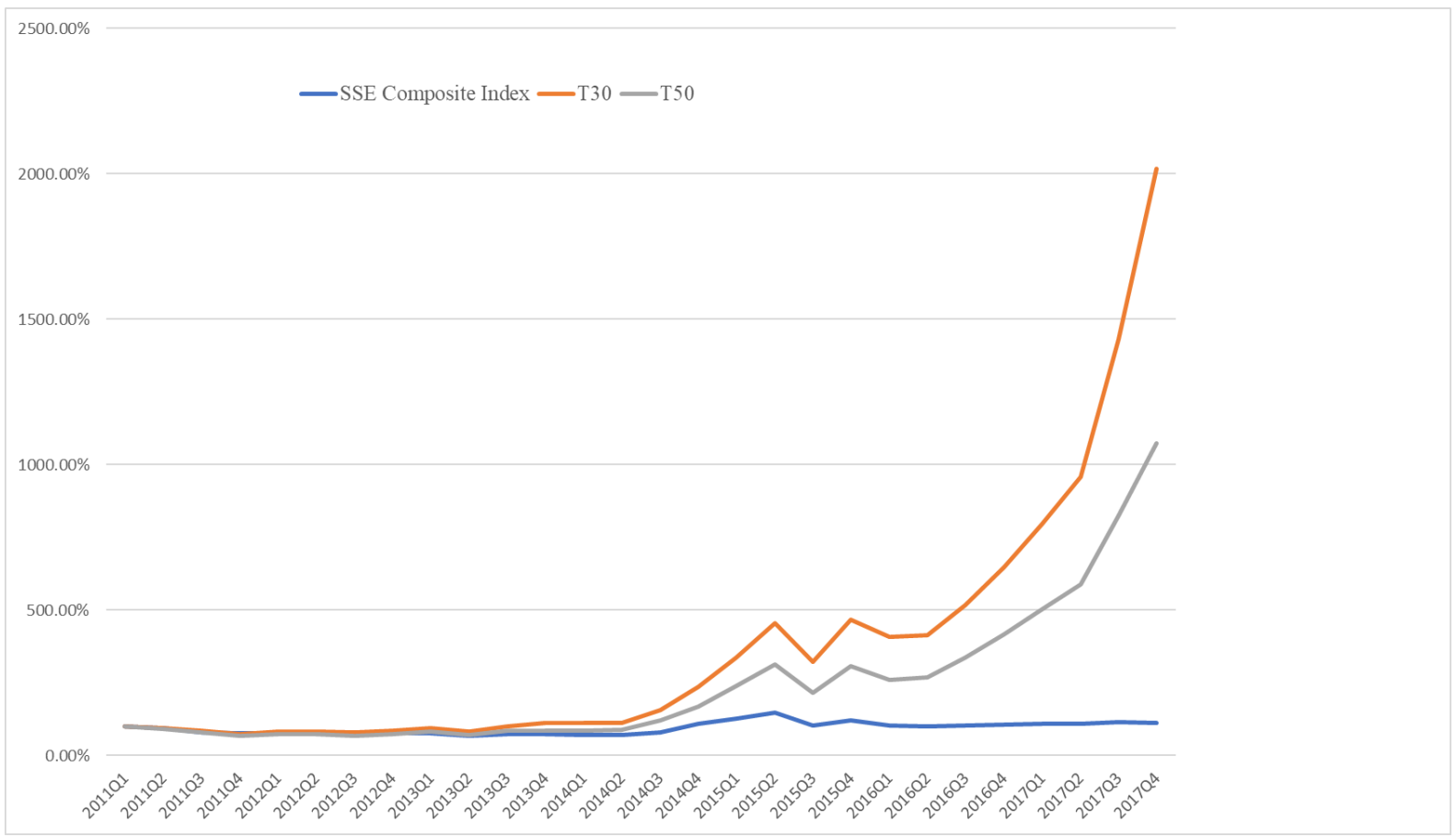

In addition, In the future research, it is suggested to consider other market boards, such as Shenzhen Main Boards, SME boards, GEM boards, to check if the leading patent indicators of different market boards are correlated or predictive. Besides, This study targets the correlation between stock price and patent indicators. Other financial indicators, such as return on equity, the market-to-book ratio, the market share rate, the rate of profit per shares, etc., are the financial indicators that are highly valued in the investment field. Whether patents have significant leadership in these important financial indicators can be studied in the future. Moreover, In this study, valid patents/invalid patents and core patents/non-core patents are not distinguished. However, on the common sense, there should be more relevant in valid patents and core patents for the financial performance of listed companies. Nevertheless, how to collect and distinguish valid patents and invalid patents and how to define core and non-core patents remains to be studied in the future. Finally, This study only focuses on Chinese mainland patents. However, the number of PCT patent applications in mainland China has been ranked among the top three in the world for five consecutive years. Whether PCT patents, other overseas patents, and family patents are also relevant to the financial performance of listed companies can be examined in the future.

\section{ACKNOWLEDGEMENT}

Authors would like to thank Shenzhen TekGlory IP Data Technologies, Ltd. and TekGlory (Beijing) Technologies, Ltd. for providing China patents raw data, patent indicators processing, stock prices collection of all A shares.

\section{REFERENCES}

Chen, R., Chang, H. Y. (2015). Expansion of design patent: from united patents to continuation patents. Total quality management and business excellence, vol.32, pp.96-103.

Ernst, H. (1995). Patenting strategies in the German mechanical engineering industry and their relationship to company performance. Technovation, vol. 15, pp.225-240.

Ernst, H. (1997). The use of patent data for technological forecasting: the diffusion of CNC-technology in the machine tool industry. Small Business Economics, vol. 9, pp.361-381.

Ernst, H. (2001). Patent applications and subsequent changes of performance: evidence from time-series cross-section analysis on the firm level. Research Policy, vol. 30, No. 1, pp.143-157.

Gao, L., Porter, A. L., Wang, J., Fang, S., Zhang, X., Ma, T. T., Huang, L. (2013). Technology life cycle analysis method based on patent documents. Technological Forecasting \& Social Change, vol.80, pp.398-407.

Grag, K. C., Padhi, P. (1998). Scientomertic study of laser patent literatüre. Scientomertics, vol.43, no.3, pp.443-454. 
Granger, C. W. J. (1969). Investing casual relations by econometric models and crossspectral method. Journal of Econometrica, vol. 37, pp.424-438.

Granger, C. W. J. (1980). Testing for causality: a personal viewpoint. Journal of Economic Dynamics and Control, vol.2, pp.329-352.

Hullmann, A., Meyer, M. (2003). Publications and patents in nanotechnology. Scientometrics, vol.58, pp. $507-527$.

Jincheol, B., Wonchang, H., Jaehong, L., Jaimin, G. (2017). Patent citations and financial analysts' long-term growth forecasts. Sustainability, vol.9, no. 5 , pp.846.

KaiP, U. (2009). Patents and profit rates. Economics Letters, vol.104, pp.79-80.

Lin, B. W., Chen, C. J., Wu, H. L. (2006). Patent portfolio diversity, technology strategy, and firm value. IEEE Transactions on Engineering Management, pp.17-26.

Mazzucato, M., Tancioni, M. (2012). R\&D, patents and stock return volatility. Journal of Evolutionary Economics, vol.22, pp. 811-832.

Narin, F. (1995). Patent as indicators for the evaluation of industrial research output. Scientomertics, vol.34, pp. 3489-496.

Shassan, M. (2016). Valuation of patents-comparative analysis. Journal of Scientometric Research, vol. 5, no. 3, pp.230-235.

Suh, J. H. (2015). Exploring the effect of structural patent indicators in forward patent citation networks on patent price from firm market value. Technology Analysis and Strategic Management, vol. 27, no. 5, pp.1-18.

Trajtenberg, M. (1990). The welfare analysis of product innovations with an application to computed tomography scanners. Journal of Political Economy, vol. 97, pp.445-479.

Vitt, C. A., Xiong, H. (2015). The impact of patent activities on stock dynamics in the high-tech. 2015 IEEE International Conference on Sector Data Mining, pp.1550-4786.

Yan, M. S., Liang, Q. Q. (2009). Patent indicator development research. Journal of Library and Information Science, vol. 35, no. 2, pp.88-106.

Zheng, X. L., Chen, B. M. (2013). Stock market modeling and forecasting: a system adaptation approach. London: Springer-Verlag. 